\title{
Loss of $\alpha$-Synuclein Does Not Affect Mitochondrial Bioenergetics in Rodent Neurons
}

DDivya Pathak, ${ }^{1}$ Amandine Berthet, ${ }^{1}$ (D) Jacob T. Bendor, ${ }^{2}$ Katharine Yu, $^{1}{ }^{1}$ Rhyomi C. Sellnow, ${ }^{3,4}$ Adam L. Orr, ${ }^{1}$ Mai K Nguyen, ${ }^{1}{ }^{\circledR}$ Robert H. Edwards, ${ }^{2}$ 'Dredric P. Manfredsson, ${ }^{3,4}$ and ${ }^{-}$Ken Nakamura ${ }^{1,2}$

DOI:http://dx.doi.org/10.1523/ENEURO.0216-16.2017

${ }^{1}$ Gladstone Institute of Neurological Disease, San Francisco, CA 94158, ${ }^{2}$ Department of Neurology and Graduate Programs in Neuroscience and Biomedical Sciences, University of California, San Francisco, San Francisco, California 94158, ${ }^{3}$ Department of Translational Science \& Molecular Medicine, College of Human Medicine, Michigan State University, Grand Rapids, MI 49503, and ${ }^{4}$ Mercy Health Hauenstein Neuroscience Center, Grand Rapids, Ml 49503

\begin{abstract}
Increased $\alpha$-synuclein ( $\alpha$ syn) and mitochondrial dysfunction play central roles in the pathogenesis of Parkinson's disease (PD), and lowering $\alpha$ syn is under intensive investigation as a therapeutic strategy for PD. Increased $\alpha$ syn levels disrupt mitochondria and impair respiration, while reduced $\alpha$ syn protects against mitochondrial toxins, suggesting that interactions between $\alpha$ syn and mitochondria influences the pathologic and physiologic functions of $\alpha$ syn. However, we do not know if $\alpha$ syn affects normal mitochondrial function or if lowering $\alpha$ syn levels impacts bioenergetic function, especially at the nerve terminal where $\alpha$ syn is enriched. To determine if $\alpha$ syn is required for normal mitochondrial function in neurons, we comprehensively evaluated how lowering $\alpha$ syn affects mitochondrial function. We found that $\alpha$ syn knockout (KO) does not affect the respiration of cultured hippocampal neurons or cortical and dopaminergic synaptosomes, and that neither loss of $\alpha$ syn nor all three $(\alpha, \beta$ and $\gamma)$ syn isoforms decreased mitochondria-derived ATP levels at the synapse. Similarly, neither $\alpha$ syn KO nor knockdown altered the capacity of synaptic mitochondria to meet the energy requirements of synaptic vesicle cycling or influenced the localization of mitochondria to dopamine (DA) synapses in vivo. Finally, $\alpha$ syn KO did not affect overall energy metabolism in mice assessed with a Comprehensive Lab Animal Monitoring System. These studies suggest either that $\alpha$ syn has little or no significant physiological effect on mitochondrial bioenergetic function, or that any such functions are fully compensated for when lost. These results implicate that $\alpha$ syn levels can be reduced in neurons without impairing (or improving) mitochondrial bioenergetics or distribution.
\end{abstract}

Key words: bioenergetics; Mitochondria; Neurodegeneration; Parkinson's Disease; Synuclein:

\section{Significance Statement}

Parkinson's disease (PD) is characterized by mitochondrial dysfunction and the accumulation of $\alpha$-synuclein ( $\alpha$ syn), and lowering $\alpha$ syn levels is a leading therapeutic strategy for PD that is already under clinical investigation. However, because $\alpha$ syn and mitochondria have intersecting functions, we must understand the impact of lowering $\alpha$ syn on mitochondrial function. We analyzed the effects of lowering $\alpha$ syn on mitochondrial bioenergetics, particularly at the nerve terminal where $\alpha$ syn concentrates. We found that loss of $\alpha$ syn does not impact the intrinsic bioenergetic function of mitochondria, suggesting that $\alpha$ syn does not normally influence respiration, and that $\alpha$ syn levels can likely be lowered without affecting mitochondrial function in PD.

\section{Introduction}

Increased $\alpha$-synuclein ( $\alpha$ syn) and mitochondrial dysfunction contribute to the pathogenesis of Parkinson's disease (PD). For example, mutation or overexpression of wild-type $\alpha$ syn and mitochondrial or mitochondriaassociated proteins (e.g., PINK1, Parkin, and CHCHD2) cause monogenic forms of PD (Polymeropoulos et al. 1997; Kruger et al. 1998; Singleton et al. 2003; Valente 
et al. 2004; Zarranz et al. 2004; Clark et al. 2006; Park et al. 2006; Funayama et al. 2015). In sporadic PD, $\alpha$ syn accumulates in Lewy bodies and dystrophic neurites (Spillantini et al. 1998), and mitochondria exhibit prominent changes, including decreased complex I activity in the substantia nigra (SN) (Schapira et al. 1990) and increased accumulation of mutations in the mitochondrial DNA of surviving SN dopamine (DA) neurons (Bender et al. 2006). In addition, changes occur in genes that regulate mitochondrial functions, including reduced expression of peroxisome proliferator-activated receptor- $\gamma$ coactivator (PGC)-1 $\alpha$ and PGC1 $\alpha$-regulated genes in SN dopamine (DA) neurons (Zheng et al. 2010).

$\alpha$ Syn and mitochondria also directly affect each other. In mice and humans, a fraction of $\alpha$ syn associates with mitochondria in DA neurons (Martin et al. 2006; Li et al. 2007; Devi et al. 2008). Additionally, supra-physiologic levels of $\alpha$ syn disrupt mitochondrial morphology in vitro and in vivo (Kamp et al. 2010; Nakamura et al. 2011; Butler et al. 2012), promote excessive mitophagy (Choubey et al. 2011; Sampaio-Marques et al. 2012), disrupt mitochondrial protein import (Di Maio et al. 2016) and influence mitochondrial $\mathrm{Ca}^{2+}$ homeostasis and apposition between the endoplasmic reticulum and mitochondria (Cali et al. 2012; Guardia-Laguarta et al. 2014). Increased $\alpha$ syn also inhibits mitochondrial complex I in cell lines and mouse brains (Devi et al. 2008; Liu et al. 2009; Chinta et al. 2010; Loeb et al. 2010), and it correlates with decreased complex I activity in mitochondrial fractions from the SN of PD patients (Devi et al. 2008).

The effects of increased $\alpha$ syn on mitochondria may result from a toxic gain-of-function, such as the accumulation of oligomeric $\alpha$ syn species that interact preferentially with mitochondria (van Rooijen et al. 2009; Nakamura et al. 2011; Nakamura, 2013; Luth et al. 2014). Moreover, even basal levels of $\alpha$ syn may predispose mitochondria to dysfunction. In $\alpha$ syn knockout (KO) mice, SN DA neurons resist toxicity from mitochondrial toxins, including 1-methyl-4-phenyl-1,2,3,6-tetrahydropyridine (MPTP) (Dauer et al. 2002; Klivenyi et al. 2006), and reducing endogenous $\alpha$ syn protects against toxicity from the complex I inhibitor rotenone (Zharikov et al. 2015) and may improve mitochondrial protein import (Di Maio et al.

unpublished reagents; $\mathrm{DP}, \mathrm{AB}, \mathrm{JB}, \mathrm{KY}, \mathrm{RS}, \mathrm{AO}, \mathrm{FM}$ and $\mathrm{KN}$ analyzed data; $\mathrm{KN}$ wrote the paper with assistance from co-authors.

This work was supported by the Joan and David Traitel Family Trust, the Michael J. Fox Foundation for Parkinson's Research, a Burroughs Wellcome Fund Medical Scientist Career Award and NIH RO1NS091902 to KN, a Cahill Family endowment and NIH R01NS062715 to RHE, and NIH RR18928 to the Gladstone Institutes.

Acknowledgements: We thank Crystal Herron and Gary Howard for helping edit this manuscript, and the S. D. Bechtel Junior Foundation for their gift of a Seahorse Analyzer to the Gladstone Institutes.

Correspondence should be addressed to Ken Nakamura, MD, PhD, Gladstone Institute of Neurological Disease, 1650 Owens Street, San Francisco, CA 94158. T: (415) 734-2550; F: (415) 355-0824; E-mail: ken.nakamura@gladstone.ucsf.edu. DOI:http://dx.doi.org/10.1523/ENEURO.0216-16.2017

Copyright $\odot 2017$ Pathak et al.

This is an open-access article distributed under the terms of the Creative Commons Attribution 4.0 International license, which permits unrestricted use, distribution and reproduction in any medium provided that the original work is properly attributed.
2016). However, excessively lowering $\alpha$ syn could also adversely affect mitochondria. While increased $\alpha$ syn causes mitochondrial fragmentation, decreased $\alpha$ syn can produce excessive mitochondrial tubulation (Kamp et al. 2010; Norris et al. 2015). Additionally, $\alpha$ syn KO mice have decreased levels of the mitochondrial lipid cardiolipin (EIlis et al. 2005) and lowering $\alpha$ syn impairs complex I/III activity, perhaps by directly interacting with complex I (Ellis et al. 2005; Devi et al. 2008). In addition, syn TKO mitochondria have decreased mitochondrial membrane potential but increased oxygen consumption, and lower activity of ATP synthase (Ludtmann et al. 2016).

Both $\alpha$ syn and mitochondria are major targets for PD therapy. Lowering $\alpha$ syn is under study in clinical trials (Dehay et al. 2015), but whether this approach is safe remains unknown. Interestingly, although single-syn KO $(\alpha, \beta$, or $\gamma)$ and double-syn KO mice $(\alpha$ and $\beta)$ have normal lifespans (Chandra et al. 2004), triple-syn KO mice $(\alpha, \beta$, and $\gamma$ ) die early (Greten-Harrison et al. 2010). These results suggest that $\alpha$ syn mediates essential functions, but other syn isoforms can compensate for its loss, at least over the lifespan of a mouse. In addition, the capacity to compensate for $\alpha$ syn loss may decrease once neuronal maturation is complete. Indeed, some studies found that lowering $\alpha$ syn in adult rodents (Benskey et al. 2016b) or non-human primates (Collier et al. 2016) using shRNA is toxic to nigral DA neurons, while other studies have not (McCormack et al. 2010; Zharikov et al. 2015), with the discrepancies likely due to varying degrees of $\alpha$ syn knockdown. Therefore, we must better understand the consequences of lowering $\alpha$ syn, particularly on mitochondrial function in axons where $\alpha$ syn concentrates and energy failure can selectively occur (Shields et al. 2015).

In this study, we aimed to determine if $\alpha$ syn is required for normal mitochondrial bioenergetics, and if $\alpha$ syn levels can be safely lowered without affecting mitochondrial bioenergetics. We comprehensively evaluated how the loss of $\alpha$ syn impacts mitochondrial function, including respiration in neurons and isolated nerve terminals, mitochondrial-derived ATP levels specifically at synapses of intact neurons, localization of mitochondria to DA synapses in vivo, and total bioenergetic function.

\section{Materials and Methods}

\section{Molecular Biology}

All constructs used for transient transfection were subcloned or cloned into the pCAGGS vector downstream of the chicken actin promoter (Voglmaier et al. 2006). The AT1.03 ${ }^{\text {YEMK }}$ FRET sensor was a kind gift from Dr Hiroyuki Noji at Osaka University (Imamura et al. 2009a). VGLUT1pHluorin-mCherry is derived from the VGLUT1-pHluorin fusion (Voglmaier et al. 2006) and was a kind gift from Dr Timothy Ryan (Weil Cornell Medical School), mCherrysynaptophysin has been described (Voglmaier et al. 2006; Hua et al. 2011), and mTagBFP was a kind gift from Dr Vladislav Verkhusha at the Albert Einstein College of Medicine (Subach et al. 2008). Mitochondria-targeted GFP (mitoGFP) and mCherry fused to the $\mathrm{N}$-terminus of rat synaptophysin (Hua et al. 2011) were subcloned into pAAV-EF1a-DIO-hChR2(H134R)-EYFP-WPRE (Addgene), 
and recombinant adeno-associated virus (AAV) 1 was made by the Vector Core at the University of North Carolina.

Viral constructs for $\alpha$ syn silencing were similar to those used before (Gorbatyuk et al. 2010); the siRNA sequences [ $\alpha$ syn: GAAGGACCAGATGGGCAAG, scrambled (SCR): GTCGACAATTCATATTTGC] were expressed as a shRNA by incorporating the loop structure TTCAAGAGA. The shRNA cassette was inserted behind an $\mathrm{H} 1$ promoter, and the viral genome also contained mTagBFP2 under the control of the hybrid chicken $\beta$-actin/cytomegalovirus enhancer promoter ( $\mathrm{pCBA}$ ) as a transduction marker. The viral vectors were packaged into AAV5 capsids by transfection of 293 cells with the viral genome and the pXYZ5 helper plasmid. Viral particles were purified using an iodixanol gradient followed by column chromatography, and titers were determined by dot-blot (Benskey et al. 2016a).

\section{Knockout and Transgenic Mice}

$\alpha$ Syn KO mice on a C57BL/6N background (strain 016123, The Jackson Laboratory) (Baptista et al. 2013) were used for most experiments. Before these mice were available, $\alpha$ syn KO mice on a mixed C57BL/6 and $129 \times$ $1 / \mathrm{SvJ}$ background (strain 003692, The Jackson Laboratory, backcrossed one generation with C57BL/6N controls) were used for experiments outlined in Fig. 2B. DATcre (Backman et al. 2006) mice were also obtained from The Jackson Laboratory. C57BL/6N mice served as controls for all studies. Mice were group-housed in a colony maintained with a standard 12-h light/dark cycle and given food on the cage floor and water ad libitum. All experiments were performed on age- and sex-matched mice. Experiments were conducted in accordance with the Guide for the Care and Use of Laboratory Animals, as adopted by the National Institutes of Health and with approval of the Authors' University Institutional Animal Care and Use Committee.

\section{Cell Culture}

Postnatal hippocampal neurons for live-imaging experiments were prepared from P0 rat (Sprague Dawley) or mouse pups. Hippocampi were dissected in $37^{\circ} \mathrm{C}$ Hanks' BSS supplemented with glucose $(20 \mathrm{mM})$ and HEPES (10 $\mathrm{mM})(\mathrm{HBSS}++)$ and plated at a density of $85 \mathrm{cells} / \mathrm{mm}^{2}$. Neurons are grown in neuronal media consisting of Earle's Minimum Essential Medium supplemented with $5 \%$ fetal bovine serum (FBS), $21 \mathrm{mM}$ glucose, 1\% Glutamax, 2\% B27 supplement (Gibco 17504-044), and $0.1 \%$ serum extender (Fisher 355006). Cells for imaging were transiently transfected by electroporation (Amaxa) and cultured for 8-14 days before live imaging or analysis (Fig. 2), or transfected with $\mathrm{Ca}^{2+}$-phosphate (Jiang and Chen, 2006) on DIV8 and cultured 14-20 days before imaging (Fig. 3). Hippocampal neurons for Seahorse experiments were prepared from E18 embryos (to minimize glial contamination (Yao et al. 2011)), plated at a density of $5 \times 10^{4}$ cells per well of a 96-well polystyrene microplate, and cultured for 10-11 days before analysis.

\section{Synaptosome Isolation}

Cortical synaptosomes were isolated from cerebral cortices of 6-month-old mice as described (Gerencser et al. 2009). Briefly, cortices were quickly dissected, rinsed, and gently homogenized in ice-cold sucrose buffer (320 mM sucrose, $1 \mathrm{mM}$ EDTA, $0.25 \mathrm{mM}$ dithiothreitol, $\mathrm{pH}$ 7.4). Homogenates were centrifuged at $1000 \times g$ for $10 \mathrm{~min}$ at $4^{\circ} \mathrm{C}$. The supernatant was layered on top of a discontinuous Percoll gradient of 3,10, and $23 \%$ Percoll layers in sucrose medium and centrifuged at $32500 \times g$ for $10 \mathrm{~min}$ at $4^{\circ} \mathrm{C}$. Synaptosomes accumulated as a band between the $10 \%$ and $23 \%$ Percoll layers and were gently aspirated and washed in HBS medium containing $20 \mathrm{mM}$ HEPES, $10 \mathrm{mM}$ D-glucose, $1.2 \mathrm{mM} \mathrm{Na} \mathrm{HPO}_{4}, 1 \mathrm{mM}$ $\mathrm{MgCl}_{2}, 5 \mathrm{mM} \mathrm{NaHCO}_{3}, 5 \mathrm{mM} \mathrm{KCl}$, and $140 \mathrm{mM} \mathrm{NaCl}$ at $\mathrm{pH}$. 7.4. The final synaptosomal pellet was resuspended in HBS medium.

To prepare dopaminergic synaptosomes, mice striata were quickly dissected and homogenized using ice-cold sucrose buffer (Choi et al. 2011). Homogenates were then incubated with antibodies against the dopamine transporter (Alpha Diagnostic International; $25 \mu \mathrm{g} / \mathrm{sample}$ ) for $60 \mathrm{~min}$ at $4^{\circ} \mathrm{C}$ and washed three times in sucrose buffer at $10000 \times g$ for $2 \mathrm{~min}$. Pellets were then incubated with $150 \mu$ l of secondary IgG magnetic beads (Miltenyi) for 45 $\min$ at $4^{\circ} \mathrm{C}$ and then poured into a magnetic column (MACS LS; Miltenyi) to separate the magnetic bead-labeled dopaminergic synaptosomes (bound to column, DA) from the nondopaminergic fraction that flows through the column.

\section{Western Blot Analysis}

Relative levels of $\alpha$ syn (1:2000; catalog \#610787, BD Biosciences, RRID:AB_398108), tyrosine hydroxylase (1:4000; catalog \#MAB318, EMD Millipore, RRID:AB_2201528), and synaptophysin (1:1000; catalog \#ab68851, Abcam, RID: AB_2199023) in dopaminergic and non-dopaminergic synaptosomes were determined by western blotting by standard procedures. Relative levels of synuclein isoforms $[\alpha$ syn (1:1000; catalog \#610787, BD Biosciences, RRID:AB_398108); $\beta$ syn (1:1000; catalog \#AB5086, EMD Millipore Chemicals, RRID: AB_2239676)] in brain lysates were also assessed by western blotting. Samples of synaptosomes $(23 \mu \mathrm{g})$ or brain lysates (25 $\mu \mathrm{g})$ were denatured by boiling in an equal volume of $2 \times$ Laemmli Lysis Buffer (Bio-Rad) for 5 min. Proteins were resolved by SDS-PAGE before transfer to PVDF membranes and detected with Pierce ECL substrate (ThermoFisher).

\section{Respiration and Glycolysis}

The extracellular-acidification rates (ECAR, a surrogate for glycolysis) and oxygen-consumption rates (OCR, assesses mitochondrial respiration) were measured in cultured hippocampal neurons using a Seahorse XF96 Extracellular Flux Analyzer (Seahorse Bioscience), an instrument that can simultaneously assess aerobic and anaerobic metabolism in adherent cells cultured in 96-well plates. Cells were washed and preincubated for $30 \mathrm{~min}$ in Seahorse assay medium ( $\mathrm{pH}$ 7.4) containing substrates of interest ( $30 \mathrm{mM}$ glucose and $10 \mathrm{mM}$ pyruvate). OCR and ECAR were measured at baseline and again after sequential addition of the respiratory inhibitors FCCP $(1 \mu \mathrm{M})$, 
rotenone $(3 \mu \mathrm{M})$, and oligomycin $(2 \mu \mathrm{M})$, or with veratridine $(50 \mu \mathrm{M})$ to increase neural activity (Lysko et al. 1994). To assess any effects of genotype on cell survival, cells in a subset of wells were also stained with DAPI (4',6diamidino-2-phenylindole) and quantified using MetaMorph software (Universal Imaging).

Aerobic respiration was also measured in cortical and dopaminergic synaptosomes prepared from $\alpha$ syn $\mathrm{KO}$ and control mice. Before plating synaptosomes, Seahorse plates were coated with $0.0033 \%(\mathrm{v} / \mathrm{v})$ polyethyleneimine solution and Geltrex suspension. Synaptosomes were then added to each well (cortical $20 \mu \mathrm{g} /$ well; dopaminergic $40 \mu \mathrm{g} /$ well), and the plates were centrifuged at $3200 \times$ $g$ for 50 mins at $4^{\circ} \mathrm{C}$ to attach the synaptosomes to the surface. For Seahorse measurements, HBS medium was replaced with Seahorse buffer containing $3.5 \mathrm{mM} \mathrm{KCl}$, $120 \mathrm{mM} \mathrm{NaCl}, 1.3 \mathrm{mM} \mathrm{CaCl}_{2}, 0.4 \mathrm{mM} \mathrm{KH}_{2} \mathrm{PO}_{4}, 1.2 \mathrm{mM}$ $\mathrm{Na}_{2} \mathrm{SO}_{4}, 2 \mathrm{mM} \mathrm{MgSO}_{4}, 10 \mathrm{mM}$ TES, $10 \mathrm{mM}$ Na-pyruvate, and $4 \mathrm{mg} / \mathrm{ml}$ bovine serum albumin.

\section{Neuronal Culture and Live Imaging}

Live imaging was performed in Tyrode's medium $\mathrm{pH}$ 7.4; $127 \mathrm{mM} \mathrm{NaCl}, 10 \mathrm{mM}$ HEPES- $\mathrm{NaOH}, 2.5 \mathrm{mM} \mathrm{KCl}, 2$ $\mathrm{mM} \mathrm{MgCl}$, $2 \mathrm{mM} \mathrm{CaCl}_{2}$, and $10 \mathrm{mM}$ pyruvate, with or without $30 \mathrm{mM}$ glucose) at room temperature (Fig. 2) on a Nikon Ti-E inverted microscope with an iXon EMCCD camera (Andor Technology) and a perfusion valve-control system (VC-8, Warner Instruments) or at $35^{\circ} \mathrm{C}$ (Fig. 3) on a Nikon Eclipse TE300 inverted microscope with a QuantEM:512SC EMCCD camera (Photometrics) controlled by MetaMorph Software. Field stimulation $(5-30 \mathrm{~Hz})$ was performed with an A385 current isolator and a SYS-A310 accupulser-signal generator (World Precision Instruments). Glycolysis was inhibited with 2-deoxyglucose (2DG, 2.5-5 mM; Sigma-Aldrich) and iodoacetate (1 mM; Sigma-Aldrich).

VGLUT1-pHluorin fluorescence images were obtained [490/20 excitation (ex), 535/50 emission (em) (Fig. 2) or 470/40 ex, 525/50 em (Fig 3); Chroma] and regions of interest were drawn over synaptic boutons, identified based on co-localization with mCherry-synaptophysin (Fig. 2) or VGLUT1-pHluorin-mCherry (Fig. 3). The background-subtracted change in fluorescence at each time point was then normalized to the fluorescence in ammonium chloride measured at the end of each run (Fig. 2) (Nemani et al. 2010) or to the peak fluorescence response $(\Delta \mathrm{F})$ to the initial stimulus train (Fig. 3). For fluorescence resonance energy transfer (FRET) experiments, sequential images were taken in the CFP [430/24 ex, 470/24 em (Fig. 2) or 436/10 ex, 465/30 em (Fig.3)], YFP [(500/20 ex, 535/30 em (Fig. 2) or 495/10 ex, 525/30 em (Fig. 3)], and FRET [(430/24 ex, 535/30 em (Fig. 2) or 436/10 ex, 525/30 em (Fig. 3)] channels with an ET ECFP/ EYFP filter set (Chroma). Synaptic boutons were identified based on co-localization with mCherry-synaptophysin. The FRET/donor ratio was calculated for each bouton as described (Xia and Liu, 2001), where FRET $=\left(I_{\text {FRET }}-I_{\text {CFP }}\right.$ $\left.* \mathrm{BT}_{\mathrm{CFP}}-\mathrm{I}_{\mathrm{YFP}} * \mathrm{~B} \mathrm{~T}_{\mathrm{YFP}}\right) / \mathrm{I}_{\mathrm{CFP}}$, such that $I_{X}$ is the background-corrected fluorescence intensity measured in a given channel. $\mathrm{BT}_{\mathrm{CFP}}$ (donor bleed through) and $\mathrm{BT}_{\text {YFP }}$ (direct excitation of the acceptor) were calculated by expressing CFP and YFP individually and then determining the ratios of $I_{\text {FRET }} / I_{\text {CFP }}$ and $I_{\text {FRET }} / I_{\text {YFP }}$, respectively.

\section{Stereotaxic Recombinant Adeno-Associated Virus and Injection}

Stereotaxic injections of adeno-associated virus 1 (AAV1) expressing mitoGFP and mCherry-Synaptophysin were performed in 3- and 7-month-old Daticre/wt and Dat ${ }^{\text {icre/wt }}$ KO mice. Briefly, $0.5 \mu \mathrm{l}$ of AAV1-EF1 $\alpha$-DIO-mitoGFP (cre-dependent mitoGFP, $8 \times 10^{12} \mathrm{VG} / \mathrm{ml}$ ) and $0.5 \mu \mathrm{l}$ of AAV1-EF1 $\alpha$-DIO-Cherry-synaptophysin (cre-dependent Cherry-synaptophysin, $3 \times 10^{12} \mathrm{VG} / \mathrm{ml}$ ) were co-injected unilaterally into the substantia nigraNTA (anteroposterior, $-3.0 \mathrm{~mm}$ from bregma; mediolateral, $1.1 \mathrm{~mm}$; dorsoventral, $4.3 \mathrm{~mm}$ ). Animals were sacrificed 4 weeks after injection. Sevenmonth-old Daticre/wt mice were co-injected with AAV1 expressing cre-dependent mitoGFP and/or cre-dependent mCherrySynaptophysin, as well as $0.5 \mu \mathrm{l}$ of either AAV2/5$\alpha$ syn-shRNA-mTagBFP2 $\left(1.8 \times 10^{13} \mathrm{VG} / \mathrm{ml}\right)$ or AAV2/5- SCRshRNA-mTagTagBFP $\left(1.1 \times 10^{13} \mathrm{VG} / \mathrm{ml}\right)$, and sacrificed 6 weeks after injection.

\section{Histology}

Mice were anesthetized and perfused with phosphate buffered saline (PBS) and then 4\% paraformaldehyde (PFA). Brains were sectioned and processed for immunofluorescence. The following primary and secondary antibodies were used: anti-tyrosine hydroxylase (TH) [(mouse, 1:20000; catalog \#MAB318, EMD Millipore, RRID:AB 2201528) and (rabbit, 1:1000; catalog \#AB152, Millipore, RRID: AB_390204)], rabbit anti-DsRed (1:1000; catalog \#632496, Clontech, RRID:AB_10015246), mouse anti- $\alpha$ syn (1:400; catalog \#610787, BD Biosciences, RRID:AB_2201528), and Alexa Fluor 488, 594, or 647 anti-mouse or -rabbit lgG (1:300; Invitrogen). Samples were imaged with the examiner blind to the genotype with a laser-scanning confocal microscope (LSM510-Meta; Carl Zeiss) equipped with $63 \times(1.4$ $\mathrm{NA})$ and $100 \times(1.3 \mathrm{NA})$ PlanApo objectives. For a given experiment, all images were captured using the same excitation and emission settings.

\section{Stereology}

Unbiased stereology was used to quantify the number of TH-positive neurons in the $\mathrm{SN}$ as described (Gorbatyuk et al. 2010). Sections were visualized using $4 x$ magnification (Olympus BX53 microscope equipped with a motorized stage (Olympus, Center Valley, PA) and a Qimaging 2000R camera (Qimaging, Surrey, BC, Canada)), and the $\mathrm{SN}$ was outlined. $\mathrm{TH}+$ cells from every sixth section were counted using the optical fractionator method with a 60x oil objective (Stereo Investigator, MBF Bioscience). The coefficient of error was calculated according to Gundersen and Jensen (Gundersen and Jensen, 1987) and was $<0.1$ (Gundersen, $\mathrm{m}=1$ ).

\section{Comprehensive Lab Animal Monitoring System Measurements}

For metabolic measurements, a Comprehensive Lab Animal Monitoring System (CLAMS, Columbus Instruments) was used to measure the rates of $\mathrm{O}_{2}\left(\mathrm{VO}_{2}\right)$ and 
$\mathrm{CO}_{2}$ consumption $\left(\mathrm{VCO}_{2}\right)$, the respiratory-exchange ratio (RER; [dot] $\mathrm{VCO}_{2} / \mathrm{NO}_{2}$ ), and the activity level of 6 -month-old male mice (Millership et al. 2012). These measurements were calculated for both the dark and light cycle for 3 consecutive days. The animals were maintained on a regular chow diet (10\% kcal from fat). The body composition (lean and fat mass) of the control and syn KO mice was also analyzed using EchoMRI (Yu et al. 2013).

\section{Results}

\section{Loss of $\alpha$ syn Does Not Affect Mitochondrial Bioenergetics at the Nerve Terminal}

To determine if $\alpha$ syn is required for neuronal respiration, we measured how $\alpha$ syn KO affects the oxygen consumption rate (OCR, a surrogate of respiration) of E18 hippocampal neuronal cultures with a Seahorse instrument. We examined hippocampal neurons because $\alpha$ syn biology has been extensively characterized in hippocampal neurons in culture and in vivo (Greten-Harrison et al. 2010; Nemani et al. 2010; Scott et al. 2010; Volpicelli-Daley et al. 2011), and $\alpha$ syn also aggregates in hippocampal neurons in PD (Hall et al. 2014). In addition, in contrast to dopamine (DA) neurons that constitute only a fraction of the total neurons in midbrain cultures, hippocampal neuronal cultures consist primarily of excitatory pyramidal neurons (Beaudoin et al. 2012), facilitating their analysis in bulk assays, such as with the Seahorse. Neuronal cultures were grown in serum-free media to minimize the glial content so that respiration is responsible for most of the OCR signal (Pathak et al. 2015). We found that $\alpha$ syn KO cultures had similar basal and maximal (after treatment with $1 \mu \mathrm{M}$ FCCP) respiration as controls (Fig. 1A, B). In addition, increasing neuronal activity with veratridine (50 $\mu \mathrm{M}$ ) augmented OCR similarly in both groups (Fig. 1C), suggesting that the respiratory function of $\alpha$ syn KO neurons upregulates normally when energy requirements are increased. Nonetheless, there was a small trend for $\alpha$ syn $\mathrm{KO}$ to have decreased basal OCR in several runs (Figs. $1 A-C)$, and we cannot exclude the possibility that $\alpha$ syn $\mathrm{KO}$ causes a small impairment in respiration that was below the sensitivity of the assay (see statistical table). Notably, $\alpha$ syn KO neurons also had similar basal rates of extracellular acidification (ECAR, a surrogate of glycolysis), which increased similarly after treatment with oligomycin $(2 \mu \mathrm{M})($ Fig. $1 D)$. These results suggest that $\alpha$ syn $\mathrm{KO}$ neurons also have normal glycolytic capacity. Notably $\alpha$ syn KO also did not affect the total number of surviving cells per well, which was assessed in a subset of wells by DAPI staining (control: 296.9 cells $/ 100 \mathrm{~mm}^{2} \pm 6.0, \alpha$ syn KO: 305.7 cells $/ 100 \mathrm{~mm}^{2} \pm 7.3$; mean $\pm \mathrm{SE}, 30$ wells per group).

The aforementioned measurements interrogate the overall respiration of neurons, but they may not be sensitive to changes in specific subcellular compartments, such as the nerve terminal. $\alpha$ Syn concentrates at synapses, which have high-energy requirements (Rangaraju et al. 2014; Pathak et al. 2015), suggesting that any effects of $\alpha$ syn KO on bioenergetics would be most prominent in this compartment. To understand the effect of $\alpha$ syn KO on respiration specifically in synapses, we ex- amined the respiration of synaptosomes isolated from the brains of 6-month-old control and $\alpha$ syn KO mice. We did not observe differences in the basal or maximal respiration in either cortical or dopaminergic synaptosomes (Fig. $1 E, F)$, although there was a small trend for decreased respiration in the $\alpha$ syn KO dopaminergic synaptosomes.

We next examined how $\alpha$ syn KO impacted ATP levels at the synapse, which reflect the balance between ATP production and consumption. $\alpha$ Syn KO and control neurons from postnatal hippocampi were co-transfected with ATP FRET sensors (Imamura et al. 2009b) and mCherrysynaptophysin to identify synaptic boutons and then cultured for 10 days before imaging. As expected, basal ATP levels were normal with glucose and pyruvate treatment in $\alpha$ syn KO neurons (Fig. 2A). To specifically examine the capacity of $\alpha$ syn KO mitochondria to produce ATP, we forced neurons to rely on mitochondria-derived ATP by acutely blocking glycolysis (switching to no-glucose media with glycolytic inhibitors). Under these conditions, the assay sensitively detects decreases in energy caused by either acute pharmacologic or chronic, genetic mitochondrial deficits. Specifically, each comparison was sensitive to an $\approx 10 \%-20 \%$ decrease in ATP FRET signal with $90 \%$ power and an alpha of 0.05 (statistical table), while the FRET must decrease by $\approx 40 \%$ from baseline to pass the threshold level (corresponding to $\approx 0.8 \mathrm{mM}$ ATP) required for endocytosis (Pathak et al. 2015; Shields et al. 2015). Furthermore, because bioenergetic deficits may only appear when energy requirements increase (Pathak et al. 2015; Shields et al. 2015), we tested if $\alpha$ syn KO influences the ability of synapses to maintain ATP levels when their energy requirements are increased (Attwell and Laughlin, 2001). Even when neural activity was augmented with electrical field stimulation ( $10 \mathrm{~Hz} * 60 \mathrm{~s}$ ) (Nemani et al. 2010), ATP levels decreased similarly with or without $\alpha$ syn (Fig. 2B, C).

We also assessed whether loss of $\alpha$ syn affected synaptic vesicle cycling (particularly endocytosis), an ATPconsuming process that is sensitive to decreases in ATP (Rangaraju et al. 2014; Pathak et al. 2015; Shields et al. 2015). To monitor synaptic vesicle cycling in individual boutons, we used the VGLUT1-pHluorin reporter, which targets a pH-sensitive GFP to the lumen of synaptic vesicles. The pHluorin does not fluoresce in acidified vesicles, but does when synaptic vesicles fuse and expose their contents to the alkaline extracellular environment (Voglmaier et al. 2006; Nemani et al. 2010). Hippocampal neurons expressing VGLUT1-pHluorin were incubated in buffer with $10 \mathrm{mM}$ pyruvate, but without glucose to favor reliance on mitochondria for energy. Even with glycolytic inhibitors, synaptic vesicle cycling $(10 \mathrm{~Hz} * 60 \mathrm{~s}$, which preferentially targets the recycling pool) was normal in synaptic boutons lacking $\alpha$ syn, further supporting that mitochondrial-derived ATP persists at functionally significant levels (Fig. 2D). Because developmental compensation may occur in $\alpha$ syn KO neurons, we also examined how knocking down $\alpha$ syn with shRNA impacts ATP levels in rat neurons. The shRNA reduced $\alpha$ syn expression by $\sim 60 \%$ based on immunofluorescence (Fig. 2E); however, 
A

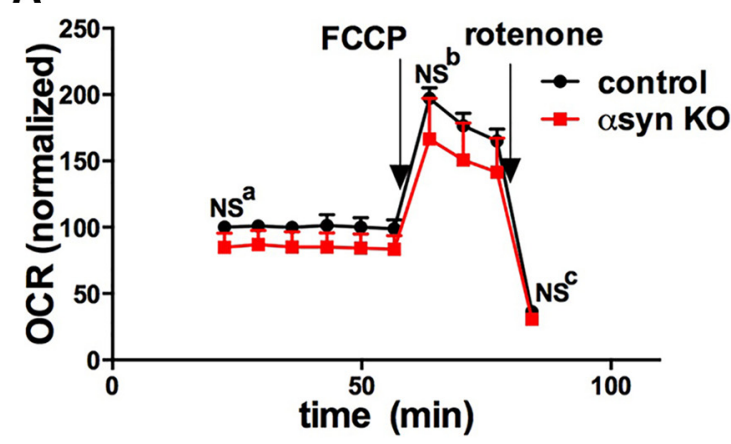

C control

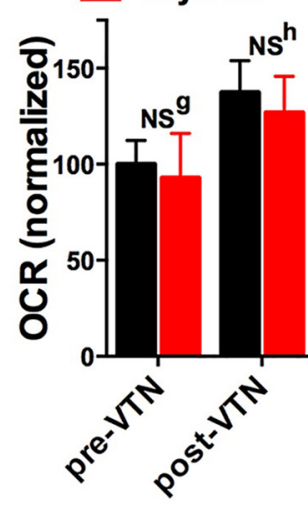

D

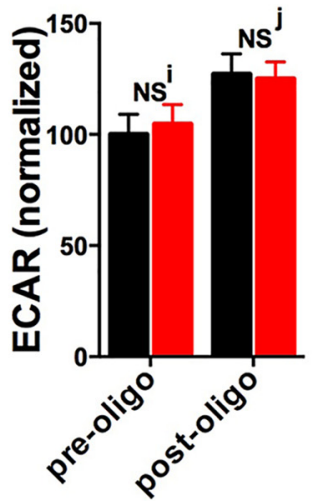

control

$\mathbf{F}$

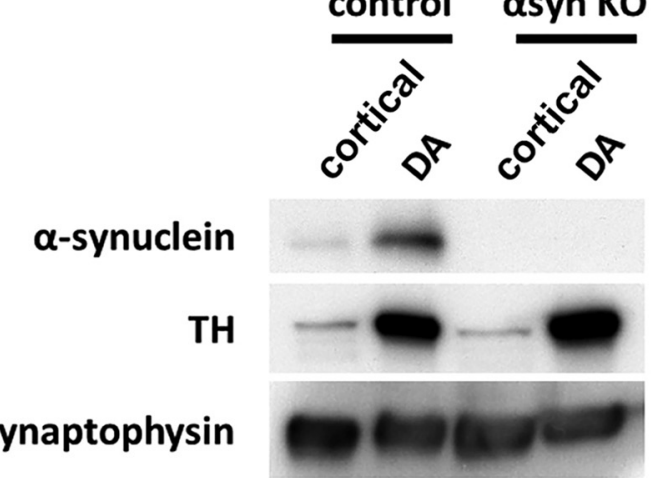

B

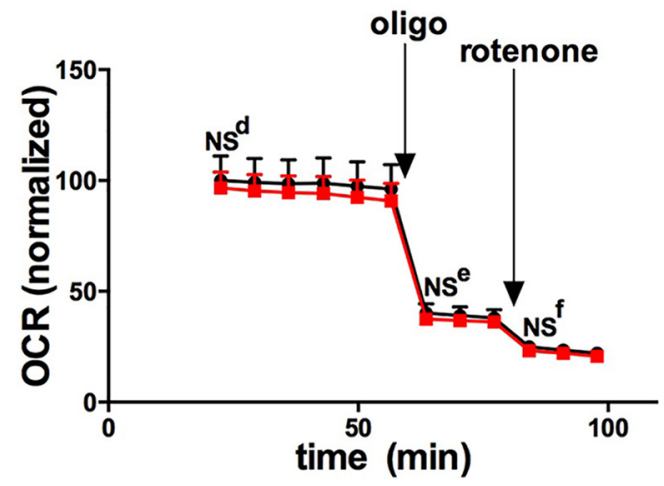

E
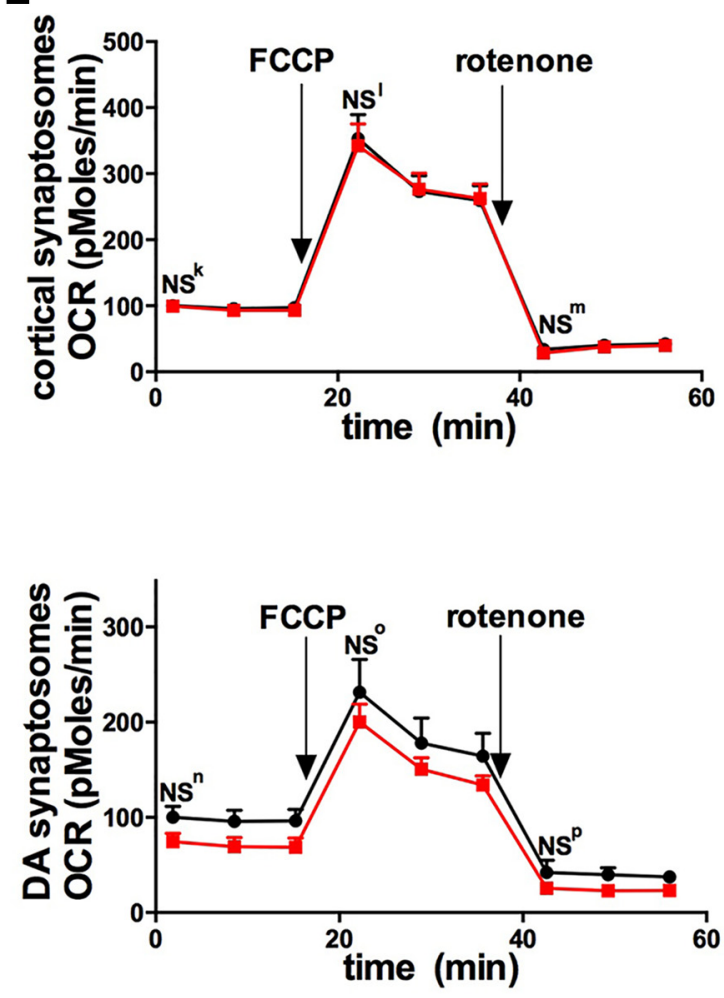

Figure 1. $\alpha$ Syn $\mathrm{KO}$ does not impact respiration in cultured neurons or synaptosomes. Aerobic respiration rates (oxygen consumption rate, OCR) were measured using a 96-well Seahorse Extracellular Flux Analyzer. Arrows show addition of the mitochondrial uncoupler FCCP (1 $\mu \mathrm{M}$ for neurons; $3 \mu \mathrm{M}$ for synaptosomes), the ATP synthase inhibitor oligomycin (oligo, $2 \mu \mathrm{M}$ ), or the mitochondrial complex I inhibitor rotenone (3 $\mu \mathrm{M}$ for neurons and synaptosomes). $\boldsymbol{A}, \alpha$ Syn KO had no effect on the basal or maximal (after FCCP) respiration of hippocampal neurons in medium containing $10 \mathrm{mM}$ pyruvate and $30 \mathrm{mM}$ glucose (compilation of two experiments, $n=13$ wells per group). B, Oligomycin and rotenone similarly decrease OCR in $\alpha$ syn KO and control groups (compilation of two experiments, $n=10$ wells per group). C, Increasing neuronal activity with veratridine similarly increased OCR (compilation of two experiments, $n$ $=6$ wells per group), while oligomycin similarly increased ECAR ( $\boldsymbol{D}$; extracellular acidification rate, a surrogate of glycolysis; compilation of two experiments, $n=9$ wells per group). $\boldsymbol{E}, \boldsymbol{F}$, cortical synaptosomes $(\boldsymbol{E})$ and dopamine (DA) synaptosomes $(\boldsymbol{F}$, right) isolated from the striatum also had similar basal and maximal rates of respiration $(n=15$ wells per group from two experiments for cortical synaptosomes; $n=7-8$ wells per group from two experiments for DA synaptosomes). As expected, western blotting ( $\boldsymbol{F}$, left) shows that both control and $\alpha$ syn KO DA synaptosomes are enriched in tyrosine hydroxylase (TH). All graphs show mean \pm SEM. NS = not significant by two-way ANOVA and Sidak's posthoc test.

this decrease did not affect synaptic vesicle cycling (Voglmaier et al. 2006; Nemani et al. 2010) (Fig. 2F).

Increased $\beta$ syn can have similar albeit less potent detrimental effects to $\alpha$ syn on mitochondrial functions (Kamp et al. 2010; Nakamura et al. 2011), and loss of all three ( $\alpha$, $\beta$ and $\gamma$, syn TKO) isoforms (but not loss of $\alpha$ syn alone) decreases mouse lifespan, raising the possibility that $\beta$ and $\gamma$ syn compensate to maintain mitochondrial function when $\alpha$ syn is lost. However, sustained electrical stimulation $(5 \mathrm{~Hz} * 475 \mathrm{~s}$ ) decreased ATP levels similarly in syn 


\begin{tabular}{|c|c|c|}
\hline $\begin{array}{l}\text { Row } \\
\text { a }\end{array}$ & $\begin{array}{l}\text { Figure } \\
1 A \text {, Seahorse-neuron-baseline }\end{array}$ & $\begin{array}{l}\text { Data } \\
\text { Distribı } \\
\text { Normal }\end{array}$ \\
\hline b & $1 A$, Seahorse-neuron-FCCP & Norm \\
\hline c & $1 A$, Seahorse-neuron-rotenone & Norm \\
\hline d & $1 B$, Seahorse-neuron-baseline & Norm \\
\hline e & $1 B$, Seahorse neuron-oligomycin & Norm \\
\hline f & $1 B$, Seahorse neuron-rotenone & Norm \\
\hline g & $\begin{array}{l}1 C, \text { Seahorse neuron pre- } \\
\text { veratridine }\end{array}$ & Norm \\
\hline h & $\begin{array}{l}1 C, \text { Seahorse neuron post- } \\
\text { veratridine }\end{array}$ & Norm \\
\hline i & $\begin{array}{l}1 D \text {, Seahorse neuron pre- } \\
\text { oligomycin }\end{array}$ & Norm \\
\hline j & $\begin{array}{l}1 D \text {, Seahorse neuron post- } \\
\text { oligomycin }\end{array}$ & Norm \\
\hline k & $\begin{array}{l}1 E, \text { Seahorse, cortical } \\
\text { synaptosomes-baseline }\end{array}$ & Norm \\
\hline I & $\begin{array}{l}1 E, \text { Seahorse, cortical } \\
\text { synaptosomes-FCCP }\end{array}$ & Normal \\
\hline m & $\begin{array}{l}1 E \text {, cortical synaptosomes- } \\
\text { rotenone }\end{array}$ & Norm \\
\hline $\mathbf{n}$ & $1 F$, DA synaptosomes-baseline & Normal \\
\hline o & $1 F$, DA synaptosomes-FCCP & Norr \\
\hline $\mathbf{p}$ & $1 F$, DA synaptosomes-rotenone & Normal \\
\hline $\mathbf{q}$ & $2 A$, baseline ATP sensor & Norm \\
\hline $\mathbf{r}$ & $2 B$, poststim1-imagea & Norm \\
\hline $\mathbf{s}$ & $2 B$, poststim1-Imageb & Norm \\
\hline $\mathbf{t}$ & $2 B$, poststim2-imagea & Norm \\
\hline $\mathbf{u}$ & $2 B$, poststim2-imageb & Norm \\
\hline $\mathbf{v}$ & $2 C$, poststim1-imagea & Norn \\
\hline $\mathbf{w}$ & $2 C$, poststim1-Imageb & Norm \\
\hline $\mathbf{x}$ & $2 C$, poststim2-imagea & Norm \\
\hline $\mathbf{y}$ & $2 C$, poststim2-imageb & Norm \\
\hline $\mathbf{z}$ & $2 D$, synKO pHluorin-stim1 & Norm \\
\hline aa & $2 D$, synKO pHluorin-stim2 & Norm \\
\hline $\mathbf{a b}$ & $2 E$, syn knockdown level & Norm \\
\hline ac & $2 F$, syn shRNA pHluorin-stim 1 & Norm \\
\hline ad & $2 F$, syn shRNA pHluorin-stim 2 & \\
\hline
\end{tabular}

$\begin{array}{llll}\text { Power for } & \text { Power for } & \text { Power for } & \begin{array}{l}\text { Value } \\ \text { detected }\end{array} \\ 10 \% & 25 \% & 50 \% & \text { with } \beta 0.1, \\ \text { change } & \text { change } & \text { change } & \alpha 0.05\end{array}$
$\begin{array}{lll}1 & 1 & 84.2\end{array}$

$\begin{array}{lll}1 & 1 & 171\end{array}$

$\begin{array}{lll}0.97 & 1 & 28.6\end{array}$

$\begin{array}{lll}0.62 & 1 & 64.5\end{array}$

$\begin{array}{lll}0.68 & 1 & 26.8\end{array}$

$\begin{array}{lll}0.71 & 1 & 16.8\end{array}$

$\begin{array}{lll}0.53 & 0.98 & 60\end{array}$

$\begin{array}{lll}0.54 & 0.98 & 83\end{array}$

$\begin{array}{lll}0.79 & 1 & 70.5\end{array}$

$\begin{array}{lll}0.93 & 1 & 97.5\end{array}$

$\begin{array}{lll}0.95 & 1 & 77.5\end{array}$

$\begin{array}{lll}0.68 & 1 & 235\end{array}$

$\begin{array}{lll}0.3 & 0.82 & 15\end{array}$

$\begin{array}{lll}0.6 & 0.99 & 63.5\end{array}$

$\begin{array}{lll}0.39 & 0.92 \quad 120\end{array}$

$\begin{array}{lll}0.13 & 0.37 & 0\end{array}$

$\begin{array}{lll}0.87 & 1 & 2\end{array}$

Unpaired Student's $t$-test $\quad 0.23$ (two-tailed)

Two-way ANOVA, Sidak's 0.97 post hoc test

Two-way ANOVA, Sidak's 0.56 post hoc test

Two-way ANOVA, Sidak's 0.41 post hoc test

Two-way ANOVA, Sidak's 0.75 post hoc test

Two-way ANOVA, Sidak's 0.89 post hoc test

Two-way ANOVA, Sidak's 0.99 post hoc test

Two-way ANOVA, Sidak's 0.82 post hoc test

Two-way ANOVA, Sidak's 0.93 post hoc test

Two-way ANOVA, Sidak's 0.51 post hoc test

Two-way ANOVA, Sidak's 0.3 post hoc test

Unpaired Student's $t$-test $\quad 0.28$ (two-tailed)

Two-way ANOVA, Sidak's 0.07 post hoc test

Two-way ANOVA, Sidak's 0.85 post hoc test

77.2 


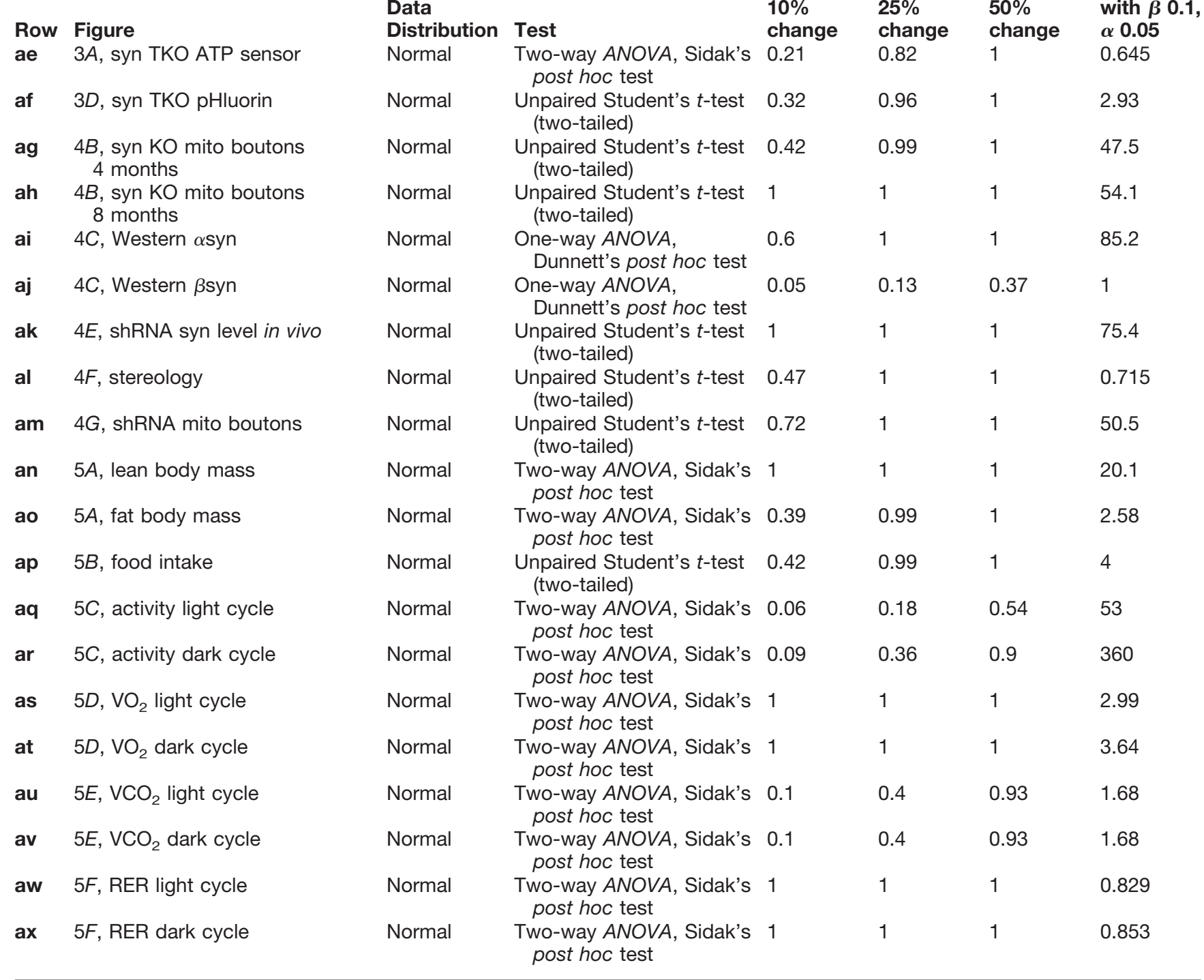

TKO and control synaptic boutons, suggesting that concurrent loss of isoforms does not affect mitochondriaderived ATP levels at the nerve terminal (Fig. 3A). As ATP levels depend on the balance between energy production (aerobic respiration and glycolysis) and consumption, we also assessed if syn TKO might impact the rate of ATP consumption. However, when energy production was blocked (the respiratory chain was blocked with rotenone $(2 \mu \mathrm{M})$, and external glucose was removed to limit glycolysis), and energy consumption was increased with repetitive electrical stimulation ( $30 \mathrm{~Hz} * 5 s$ every $120 \mathrm{~s})$, the stimulus-dependent endo- and exocytic response of syn TKO and control boutons failed at the same rate (Fig. $3 B-D$ ), indicating that ATP levels fell below the threshold level needed to support synaptic vesicle cycling at the same rate (Pathak et al. 2015; Shields et al. 2015). Since the ATP level reflects a balance between ATP production and consumption, these results suggest that the net balance of ATP consumption and any residual ATP produc- tion by glycolysis is also similar in syn TKO and control synaptic boutons.

\section{Lowering $\alpha$ syn Does Not Impact Mitochondrial Distribution in Axons}

Even when the intrinsic function of individual mitochondria is normal, changes in the distribution of mitochondria could create regions within neurons (especially axons) without sufficient mitochondria to meet energy requirements, leading to energy failure in that region. $\alpha$ Syn primarily locates to presynaptic terminals (Jakes et al. 1994; Iwai et al. 1995), and mutant A53T $\alpha$ syn decreases the movement and density of mitochondria in axons (Choubey et al. 2011; Li et al. 2013). To determine if endogenous $\alpha$ syn influences the localization of axonal mitochondria to synapses, we used cre-dependent AAVbased viral reporters to visualize mitochondria [mitochondrial-targeted GFP (mitoGFP)] specifically in individual DA neurons and their synapses (mCherry- 


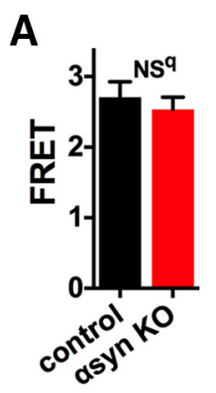

B
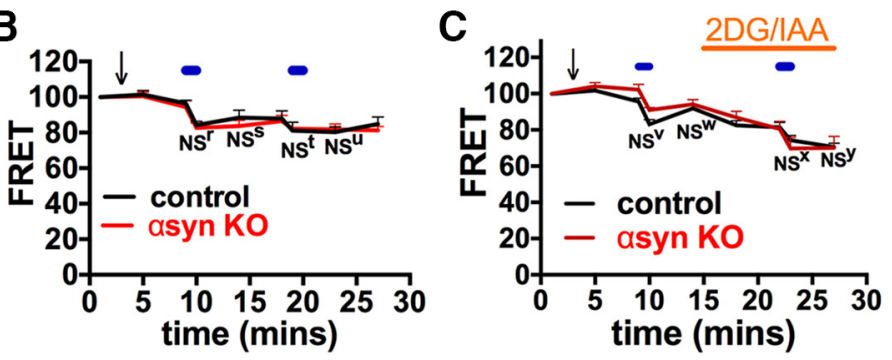

D

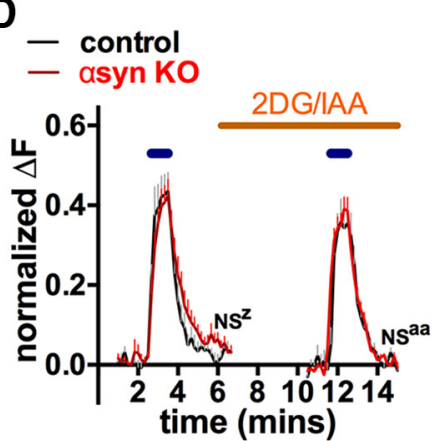

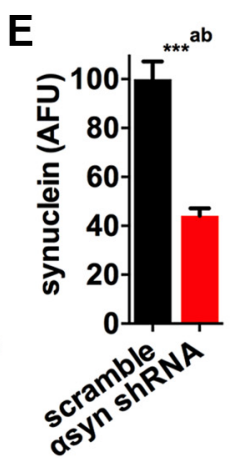

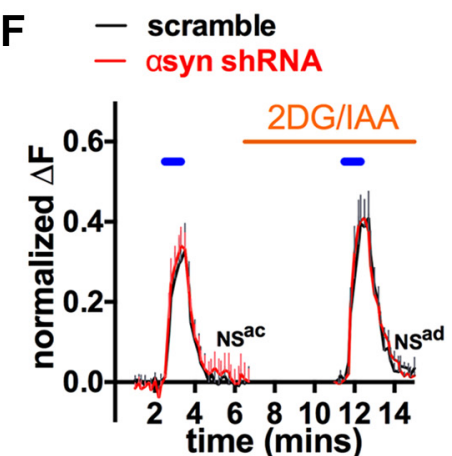

Figure 2. Loss of $\alpha$ syn does not affect mitochondrial-derived ATP levels at the nerve terminal. A-C, ATP levels of hippocampal neurons were assessed using an ATP YEMK FRET sensor, and synaptic boutons were identified with mCherry-synaptophysin. Basal ATP levels in Tyrodes buffer containing glucose and pyruvate were identical in neurons isolated from control and $\alpha$ syn KO mice (A; $n=14-15$ coverslips, not significant (NS) by unpaired two-tailed $t$ test). Electrical field stimulation (10 Hz $* 60 \mathrm{~s}$, blue lines) in pyruvate buffer without $(\boldsymbol{B})$ and with $(\boldsymbol{C})$ 2-deoxyglucose (2DG, $5 \mathrm{mM}$ ) and iodoacetate (IAA, $1 \mathrm{mM})$ to completely block glycolysis reduced ATP levels similarly in neurons in control and $\alpha$ syn KO mice (compilation of two experiments, $n=6-7$ coverslips/group with $15-20$ boutons/coverslip). NS for ATP level of $\alpha$ syn KO versus control groups at corresponding time points. Note that overall ATP levels (control and $\alpha$ syn $\mathrm{KO}$ ) decreased after the first electrical stimulation ( $\boldsymbol{B}$ and $\boldsymbol{C}, \mathrm{p}<0.01$ for ATP at 10 min versus 9 min pre-stimulation time points), while the acute drop in ATP levels after the second stimulations did not reach significance. $\boldsymbol{D}-\boldsymbol{F}$, Synaptic transmission at individual boutons was assessed using a pH-sensitive GFP targeted to synaptic vesicles (VGLUT1-pHluorin), again in pyruvate buffer, as well as 2DG and IAA to force reliance on glycolysis. Neither $\alpha$ syn KO (D) or shRNA against $\alpha$ syn $(\boldsymbol{E}, \boldsymbol{F})$ affected synaptic vesicle cycling after repeated stimulation $(10 \mathrm{~Hz} * 60 \mathrm{~s}$, blue lines). Bar graph confirms that shRNA decreased $\alpha$ syn levels by immunofluorescence $(E)$ (compilation of three experiments, $n=10-12$ coverslips/group with 10-15 cells/coverslip). NS for extent of endocytosis [(amplitude endocytosis)/(amplitude exocytosis)] versus respective control by two-way ANOVA and Sidak's posthoc test. All graphs show mean \pm SEM.

synaptophysin) (Berthet et al. 2014) in DATcre control and $\alpha$ syn KO-DATcre mice that express Cre recombinase selectively in S/c6a3 (dopamine transporter, DAT)expressing DA neurons (Backman et al. 2006). $\alpha$ Syn KO did not affect the proportion of DA boutons containing mitochondria $(\sim 60 \%)$ in the caudate putamen (CPu) (Fig. $4 A, B)$.

Notably, $\alpha$ syn KO mice may have developmental changes that compensate for the loss of $\alpha$ syn (Kuhn et al. 2007). Although we did not detect changes in the level of $\beta$ syn in total brain lysates (Fig. 4C), other groups found it upregulated in the midbrain of $\alpha$ syn KO mice (Robertson et al. 2004; Thomas et al. 2011) and that compensation could occur independent of changes in expression. To further exclude the possibility of any developmental compensation, we also examined if lowering $\alpha$ syn with shRNA in adult mice (Gorbatyuk et al. 2010; Kanaan and Manfredsson, 2012) would impact the axonal localization of mitochondria. Using AAV expressing an shRNA against $\alpha$ syn, we lowered $\alpha$ syn levels in DA neurons by $\sim 60 \%$ (Figs $4 D-E, 4 \mathrm{E}-1$ ) (as measured by immunofluorescence), a level of decrease that may not be quite sufficient to produce neuronal loss in rats (Gorbatyuk et al. 2010), and mice may also be more resistant (Benskey et al. 2016b). Consistent with this, there was no significant loss of DA neurons in the $\alpha$ syn shRNA group (Fig. 4F), although there was a trend for decreased TH+ counts. This level of $\alpha$ syn decrease also did not affect the proportion of boutons containing mitochondria (Fig. 4G). Therefore, $\alpha$ syn levels can be significantly lowered in DA neurons without impacting the synaptic targeting of mitochondria. We cannot exclude the possibility that further lowering of $\alpha$ syn by shRNA such that the DA neurons die would have disrupted mitochondria, and it would be difficult to attribute such a change specifically to $\alpha$ syn lowering as mitochondria are typically disrupted during neuronal death, regardless of the cause. Nonetheless, when considered with the lack of effect in $\alpha$ syn KO mice, our data suggest that either $\alpha$ syn does not normally impact mitochondrial distribution in DA axons or that other factors compensate for $\alpha$ syn loss (Nakamura et al. 2011).

$\alpha$ Syn is expressed throughout the brain, including in regions that influence respiration and metabolism. $\alpha$ Syn is also present at high levels in certain peripheral tissues including in red blood cells, liver and spleen (Kuo and Nussbaum, 2015), and phosphorylated $\alpha$ syn accumulates 
A

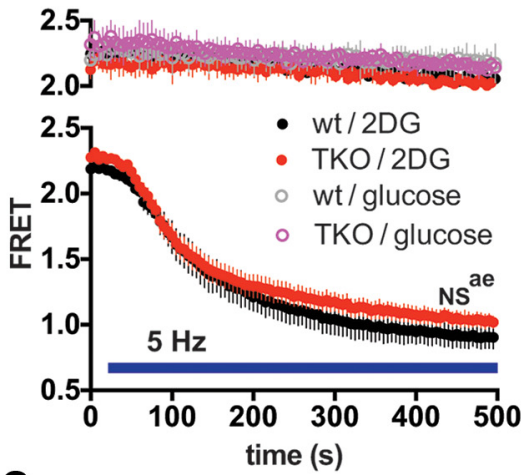

C
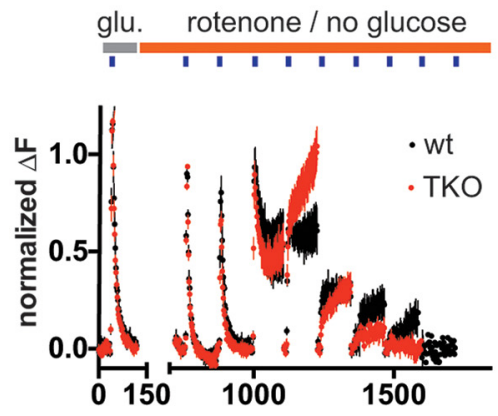

B

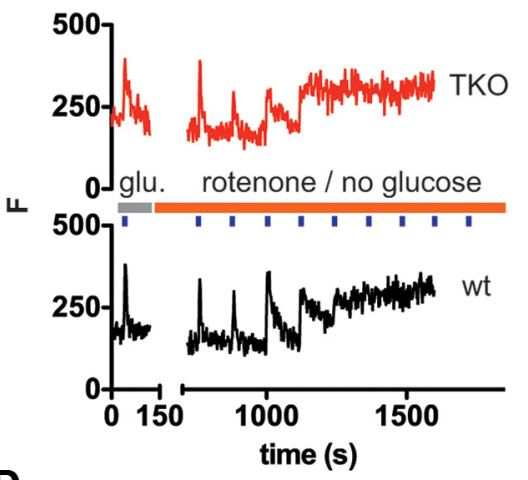

D

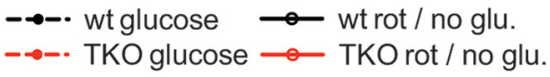

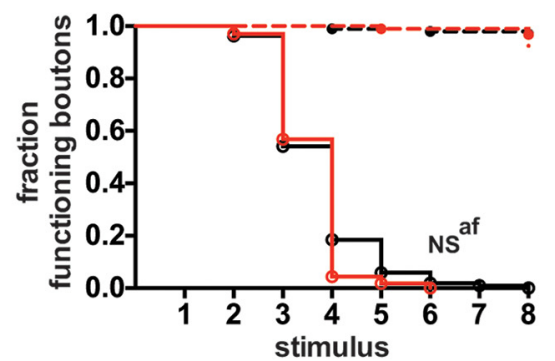

Figure 3. Loss of all three $(\alpha, \beta$ and $\gamma$ ) syn isoforms does not affect mitochondria-derived ATP or activity-dependent ATP consumption at the nerve terminal. (A) ATP levels of syn TKO and control hippocampal neurons expressing the ATP FRET sensor were assessed in normal Tyrode's buffer with either glucose $(30 \mathrm{mM})$ or 2DG $(30 \mathrm{mM})$ without glucose. Neurons were imaged with or without electrical field stimulation $(5 \mathrm{~Hz})$ as indicated. Stimulation with $5 \mathrm{~Hz}$ for $475 \mathrm{~s}$ in 2DG decreased the FRET signal similarly in wt and TKO neurons (2-way ANOVA, interaction $\mathrm{p}>0.99$ ) Data are plotted as mean \pm SEM by coverslip. $n=4$ (wt) and 5 (TKO) coverslips for $5 \mathrm{~Hz}$ stimulus/2DG, and 2 coverslips (wt and TKO) for non-stimulated glucose and 2DG controls (50 boutons per coverslip) (B-D) Neurons expressing VGLUT1-pHluorin-mCherry were perfused in Tyrodes containing $30 \mathrm{mM}$ glucose (without pyruvate) and stimulated at 30 $\mathrm{Hz}$ for $5 \mathrm{~s}$. After continued perfusion for $5 \mathrm{~min}$ in either glucose or in $2 \mu \mathrm{M}$ rotenone without glucose, neurons were stimulated with repeated 5 s $30 \mathrm{~Hz}$ bursts every $120 \mathrm{~s}$ (blue boxes). (B) Sample fluorescence traces from single representative VGLUT1-pHluorin boutons in wild-type (lower) and syn TKO (upper) neurons in rotenone, (C) Average fluorescence responses. Data were normalized to the second stimulus response, and points represent mean values by coverslip \pm SEM. $n=7$ (wt) and 8 (TKO) coverslips (18-50 boutons per coverslip) for pyruvate/rotenone experiments, from two independent experiments. (D) Fluorescence traces from individual boutons (as in (A)) were scored with regard to synaptic vesicle cycling response at each stimulus burst. The stimulus burst at which the response "failed" was recorded, and data were plotted as survival curves. Boutons were scored as failed if stim $\Delta \mathrm{F}$ was $<10 \%$ of the $\Delta \mathrm{F}$ from first stim, or if $\Delta \mathrm{F} 120$ s after stimulus was $>33 \%$ of the peak Fstim-F0 value (ie endocytic failure). Wt and syn TKO boutons in rotenone without glucose progressively failed to respond at a similar rate ( $p=0.21$ by Gehan-Breslow-Wilcoxon test). $n=325$ (wt) and 340 (TKO) boutons for rotenone/no glucose, 98 (wt) and 93 (TKO) boutons for glucose-containing Tyrode's. The average lifespan of boutons by coverslip in rotenone/no glucose was also similar (wt $=3.75 \pm 0.253$ and syn TKO $=3.61 \pm 0.137$ ).

in peripheral tissues in PD (Beach et al. 2010). However, there is very little information on if $\alpha$ syn expression in these areas impacts metabolic functions. Because $\alpha$ synlowering therapies will likely lower $\alpha$ syn levels throughout the brain and in peripheral tissues, we also examined if interactions between $\alpha$ syn and mitochondria affect energy metabolism on a whole-body level using metaboliccage analyses and CLAMS (Columbus Instruments). At 6 months of age, $\alpha$ syn KO mice had total and lean body masses similar to controls, as assessed by EchoMRI (Fig. $5 A$ ). Food consumption (Fig. 5B) and total locomotor activity (Fig. $5 \mathrm{C}$ ) were also unchanged, although the assessment of activity lacked sensitivity due to high variability, and there was a trend toward less movement in the dark cycle in the $\alpha$ syn KO group. However, importantly, $\alpha$ syn $\mathrm{KO}$ did not affect oxygen consumption $\left(\mathrm{VO}_{2}\right)$, carbon dioxide production $\left(\mathrm{VCO}_{2}\right)$, or the respiratory-exchange ratio (RER; [dot] $\mathrm{VCO}_{2} / \mathrm{VO}_{2}$ ) in either the light or dark cycle (Fig $5 D-F$ ). Taken together, these data strongly suggest that loss of $\alpha$ syn does not impact total energy consumption in mice.

\section{Discussion}

$\alpha$ Syn likely plays a central role in the pathogenesis of sporadic PD. Mitochondria are also compromised in PD, so therapeutic lowering of $\alpha$ syn will be done in the context of damaged mitochondria. In addition, increased $\alpha$ syn disrupts a range of mitochondrial functions, suggesting that decreasing $\alpha$ syn also influences mitochondrial function. However, here, we show that loss of $\alpha$ syn does not significantly impact the intrinsic bioenergetic function of mitochondria (i.e., respiration and ATP levels) in rodent neurons, even regionally at the synapse where $\alpha$ syn concentrates. Loss of $\alpha$ syn also fails to influence the local- 
A $\begin{gathered}\text { mCherry- } \\ \text { synaptophysin }\end{gathered}$
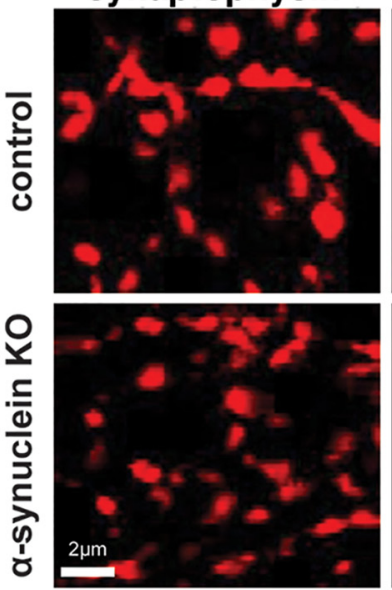

C

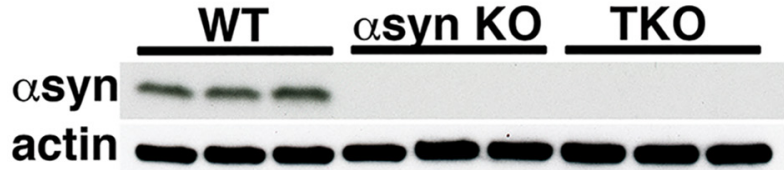

ßsyn actin

D
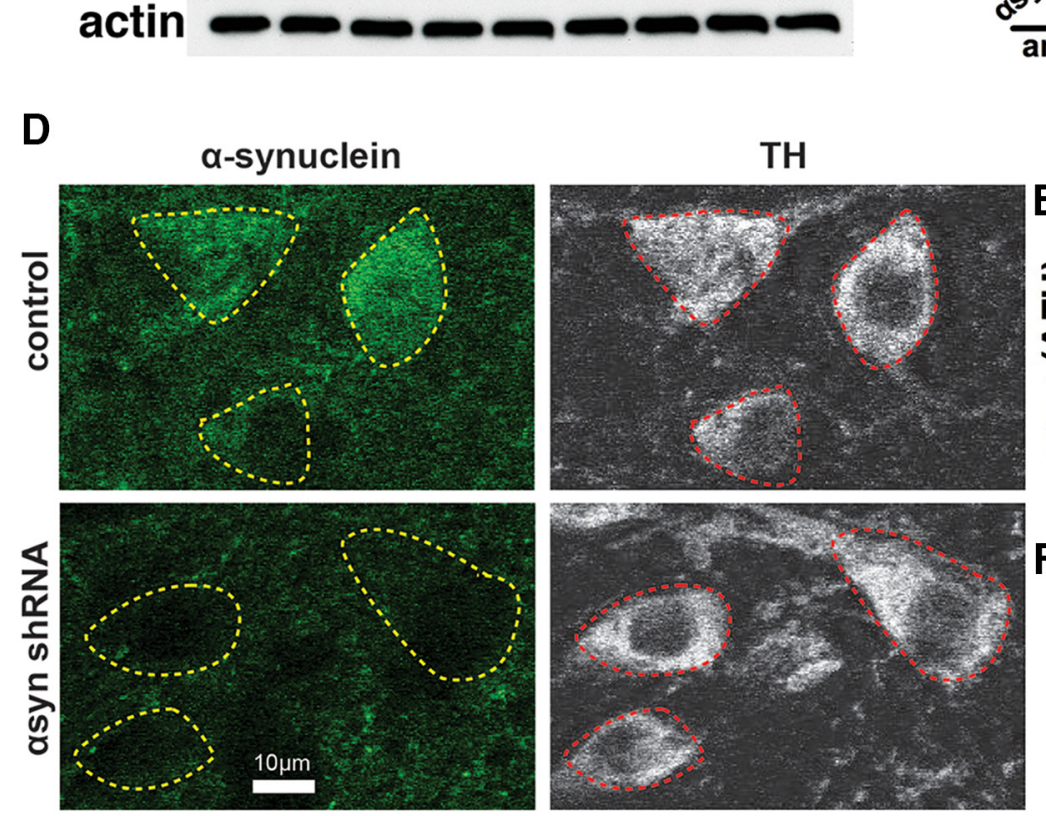

mitoGFP
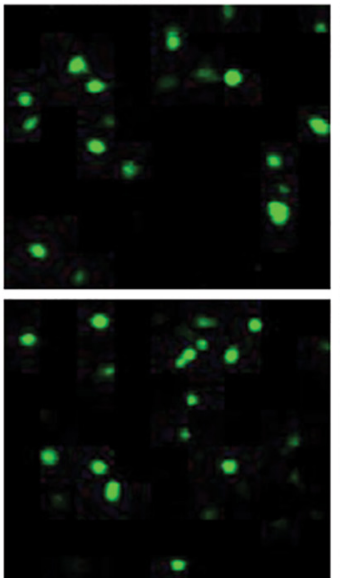

B
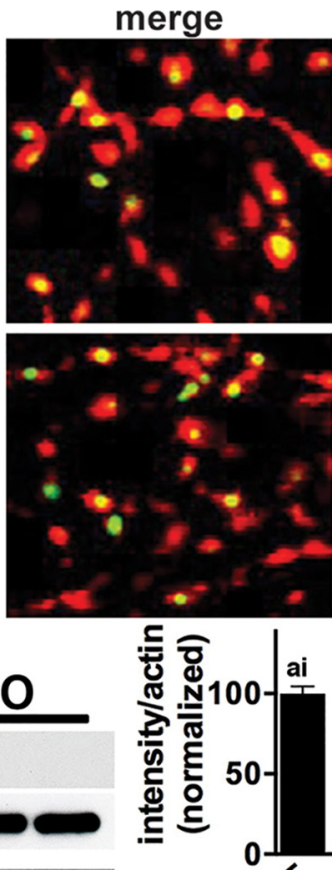

(1) control

asyn KO

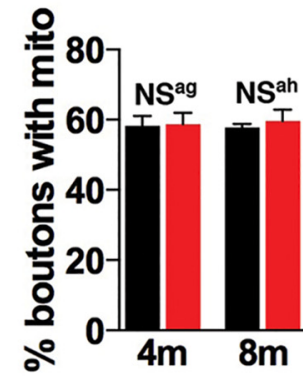

aj
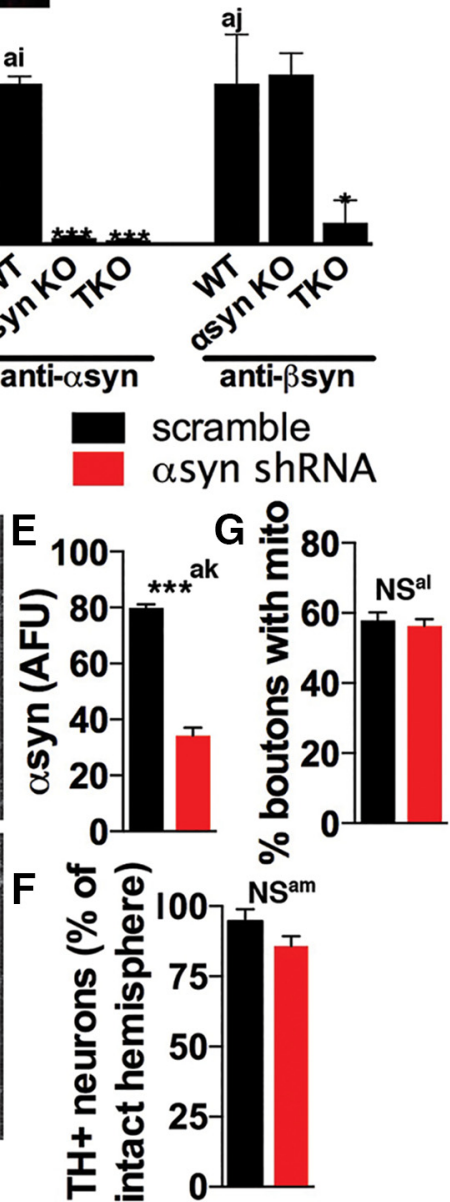

Figure 4. Loss of $\alpha$ syn does not affect the distribution of mitochondria in axons of nigrostriatal DA neurons in vivo. A-B, Adeno-associated viruses (AAVs) expressing mitochondria-targeted GFP (mitoGFP; green, to visualize mitochondria) and mCherrySynaptophysin (red, to visualize synaptic boutons) in DIO constructs (Sohal et al. 2009) that express only in Cre-expressing neurons were coinjected into the substantia nigra pars compacta (SNc) of 3- and 7-month-old DATcre control and $\alpha$ syn KO-DATcre mice. Mice were sacrificed one month later at 4 and 8 months of age, respectively. Roughly $60 \%$ of control and $\alpha$ syn KO synaptic boutons show mitochondria in the caudate putamen $(\mathrm{CPu})(n=3-4$ mice per group, where each value is the mean of $18-21$ fields; NS = not significant by two-way ANOVA and Sidak's posthoc test). $\boldsymbol{C}$, Western blot shows that $\alpha$ syn KO mice have similar levels of $\beta$ syn as controls ( $n=3$ mice per group; $* p<0.05$, ***p $<0.001$ by one-way ANOVA and Dunnet's posthoc test). D-G, AAVs expressing expressing mitoGFP and mCherry-Synaptophysin in DIO constructs were co-injected with shRNA scramble TagBFP or shRNA $\alpha$ syn TagBFP into the SNc of 7-month-old Dat ${ }^{\text {icre/wt }}$ mice, and brains were harvested 6 weeks later. $\boldsymbol{D}-\boldsymbol{E}$, shRNA against $\alpha$ syn decreased $\alpha$ syn immunofluorescence $\sim 60 \%$ versus shRNA scramble in DA neurons $(n=3-4$ mice, $57-86$ cells per mouse ( $\alpha$ syn immunofluorescence level of individual cells for each mouse is shown in Fig. 4E-1); $* \mathrm{p}<0.001$ by unpaired two-tailed $t$ test), identified by 
continued

tyrosine hydroxylase $(\mathrm{TH})$, but had no effect on either the number of $\mathrm{TH}+$ neurons as measured by stereology $(\boldsymbol{F} ; n=6-8$ mice per group; $\mathrm{NS}=$ not significant $(\mathrm{p}=0.16)$ by unpaired two-tailed $t$ test) or on the localization of mitochondria to synaptic boutons $(\mathbf{G} ; n=3-4$ mice per group, where each value is the mean of 6-10 fields; NS = not significant by unpaired two-tailed $t$ test). All graphs show mean \pm SEM.

ization of mitochondria in DA axons or disrupt normal energy consumption in the whole body. Thus, our findings suggest that either $\alpha$ syn has no significant physiologic impact on mitochondrial bioenergetic function, or that any such functions are fully compensated for when lost or emerge only in the presence of specific stressors.

Increased $\alpha$ syn expression selectively inhibits complex I function (Devi et al. 2008; Liu et al. 2009; Chinta et al. 2010; Loeb et al. 2010) or the flux between complex I and III (Ellis et al. 2005; Devi et al. 2008). However, we do not yet understand the precise mechanisms of these effects or if the decrease in complex I function impacts energy production. Insufficient energy could also result from changes in the mass or distribution of mitochondria, even if the mitochondria have normal function. Indeed, increased mutant A53T $\alpha$ syn augments Parkin-dependent mitophagy in cortical neurons (Choubey et al. 2011) and the number of mitochondria in autophagosomes in midbrain DA neurons (Chinta et al. 2010). However, we found that decreased $\alpha$ syn did not affect the bioenergetic function of mitochondria, including regionally at the synapse, or the mass or distribution of mitochondria in nigrostriatal DA neurons in vivo.

The lack of effect of $\alpha$ synKO on bioenergetic function has three potential explanations. The first is that $\alpha$ syn KO does actually impair bioenergetic function but our studies failed to detect this due to insufficient sensitivity. Indeed, many of our assays lacked the sensitivity to reliably detect changes less than $\approx 10 \%-15 \%$, and hence, subtle changes would not have been detected. However, all of the approaches used to assess bioenergetic function have been validated for their sensitivity to detect the effects of acute pharmacologic and chronic genetic inhibitors of respiration, and the uniform lack of significant changes across multiple complementary approaches provides strong evidence that $\alpha$ syn KO does not significantly impact bioenergetic function in the paradigms studied. Insufficient sensitivity could also have resulted if we assayed the wrong type of cell or the wrong subcellular compartment. In particular, our study focuses on neurons because $\alpha$ syn primarily localizes to neurons normally and accumulates in neurons in PD. Moreover, within neurons, we focused on synapses where most $\alpha$ syn KO localizes. To specifically assay nigrostriatal DA neurons we examine DA synaptosomes. However, recognizing the potential for artifact from the antibody bead-based isolation of DA synaptosomes, we also examined cortical synaposomes that were isolated without use of antibodies. Since synaptosomes likely have distinct bioenergetic properties from intact neurons, and even the standard isolation of

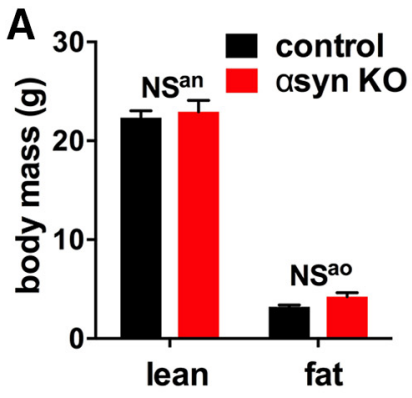

D

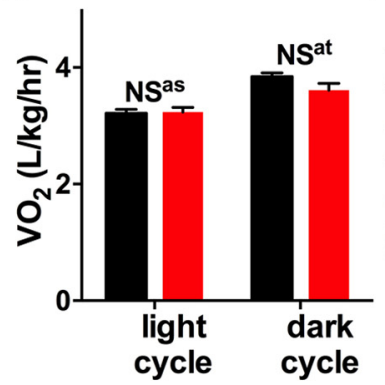

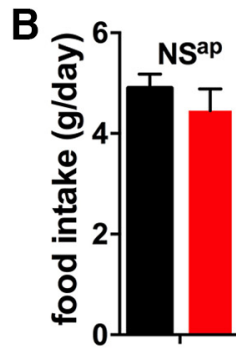

E

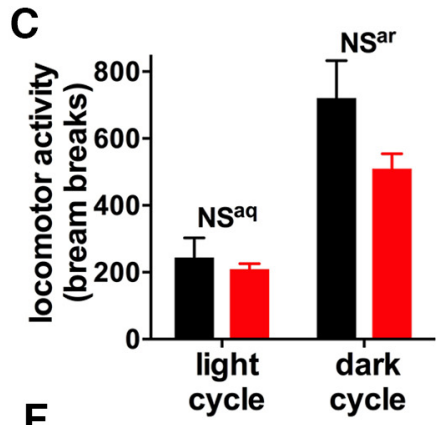

$\mathbf{F}$

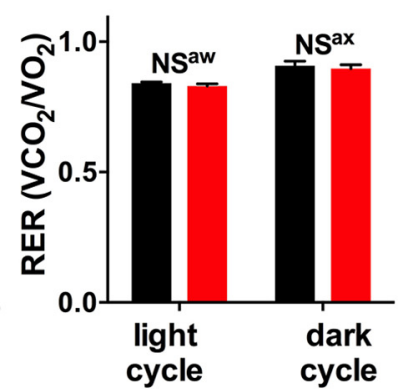

Figure 5. $\alpha$ syn KO does not impact total body metabolism in mice. A, Body composition was measured using EchoMRI. Control and $\alpha$ syn $\mathrm{KO}$ had identical lean and fat body mass composition at 6 months of age. $\boldsymbol{B}-\boldsymbol{F}$, Body metabolism was assessed using a Comprehensive Lab Animal Monitoring System (CLAMS; Columbus Instruments). $\alpha$ syn KO and control mice had similar daily food intake $(\boldsymbol{B})$ and locomotor activity $(\boldsymbol{C})$. They also had similar $\mathrm{VO}_{2}(\boldsymbol{D}), \mathrm{V}_{\mathrm{CO}_{2}}(\boldsymbol{E})$, and respiratory exchange ratio $\left(\mathrm{RER}\right.$, ratio of $\mathrm{VcO}_{2}$ produced and $\mathrm{VO}_{2}$ used) $(\boldsymbol{F})$ during both the light and dark cycles. $n=6$ mice per group; NS = not significant by two-way ANOVA and Sidak's posthoc test. All graphs show mean \pm SEM. 
cortical synaptosomes may introduce artifacts, we assayed mitochondria-derived ATP levels in individual synaptic boutons of live neurons in complementary assays.

Insufficient sensitivity for an effect of decreasing $\alpha$ syn on bioenergetics could also have resulted if decreasing $\alpha$ syn affects only certain neuron types that we failed to assay. For instance, although we assayed DA neurons when possible, many of our assays focused on hippocampal neurons. However, we hypothesize lowering $\alpha$ syn will have similar effects across most neuron types. Indeed, $\alpha$ syn is present in neurons throughout the brain and, undoubtedly, has normal functions outside of nigrostriatal DA neurons. (Bendor et al. 2013; Benskey et al. 2016b) Thus, we must understand the impact of lowering $\alpha$ syn on nonDA neurons, in addition to DA neurons, since any $\alpha$ syn lowering therapy will likely be delivered to the entire brain. Moreover, the fact that human nigrostriatal DA neurons are susceptible to increased $\alpha$ syn in familial forms of PD does not mean they will also be more susceptible to $\alpha$ syn loss. In fact, it could mean just the opposite, and the underlying mechanisms of toxicity of increasing versus decreasing $\alpha$ syn could also be very different. For instance, increased $\alpha$ syn in some forms of PD may cause toxicity through a toxic gain of function of $\alpha$ syn, but loss of $\alpha$ syn could produce toxicity through loss of its normal function. Moreover, in PD, $\alpha$ syn accumulates in many nonDA neurons, including hippocampal neurons (e.g., see Hall et al. Brain, 2014), presumably contributing to the many non-motor features of the disease. As such, hippocampal neurons are an important and appropriate system to study normal $\alpha$ syn biology, and the wealth of preexisting studies in this neuron type facilitates interpretation of our results. However, the possibility remains that $\alpha$ syn-lowering compromises bioenergetics only in certain other neuron types.

A second possibility for a lack of effect of decreasing $\alpha$ syn on bioenergetic function is that $\alpha$ syn may normally interact with mitochondria and influence respiration, but the effects of $\alpha$ syn loss may be compensated for by other factors, such as $\beta$ syn, which has similar, albeit less, potent effects on mitochondrial morphology when overexpressed (Nakamura et al. 2011; Taschenberger et al. 2013). Indeed, the three syn isoforms can compensate for each other, because $\alpha$ syn, $\beta$ syn, and $\gamma$ syn single-KO mice and $\alpha$ syn/ $\beta$ syn double-KO mice have normal lifespans (Chandra et al. 2004), but triple syn-KO mice die early (Greten-Harrison et al. 2010). As evidence against this possibility, however, we found no effect of synTKO on mitochondria-derived ATP levels at the nerve terminal or on the rate of ATP consumption. In apparent contradiction, Ludtmann et al. (Ludtmann et al. 2016) recently reported that synTKO neurons have impaired bioenergetic function, suggesting that other syn isoforms compensate for certain $\alpha$ syn-effects on mitochondria. The reasons for this discrepancy are unclear, but could reflect differences between subcellular compartments. Specifically, our studies on synTKO neurons focused on changes at the nerve terminal where $\alpha$ syn and $\beta$ syn accumulate. They also observed ATP changes using a mitochondriatargeted ATP sensor, while we examined cytosolic ATP levels, raising the possibility that synuclein isoforms might specifically alter ATP levels in the mitochondria. However, other methodological differences including the use of permeabilized versus intact neurons and the use of $\mathrm{Mg}^{2+}$ homeostasis (versus our use of synaptic vesicle cycling) to assay for ATP consumption may also underlie some of the differences, and will require additional experimentation to resolve.

A third possibility is that $\alpha$ syn normally has minimal interactions with mitochondria and little effect on bioenergetic function. Although increased $\alpha$ syn disrupts mitochondrial morphology and function, these effects may reflect direct toxicity from the interaction of $\alpha$ syn oligomers with mitochondria (van Rooijen et al. 2009; Nakamura et al. 2011; Nakamura, 2013; Luth et al. 2014), and they may not occur under normal conditions. Also, while endogenous $\alpha$ syn can influence mitochondrial morphology (Kamp et al. 2010; Norris et al. 2015), and disrupt mitochondrial protein import (Di Maio et al. 2016), these changes may not be sufficiently robust to compromise respiration under basal conditions, although may be more prominent under pathologic conditions as in PD. Furthermore, although $\alpha$ syn KO mice resist MPTP and other mitochondrial toxins (Dauer et al. 2002; Klivenyi et al. 2006), and decreasing endogenous $\alpha$ syn levels protects against rotenone (Zharikov et al. 2015), the mechanism of these effects may be independent of bioenergetic function and the other parameters studied here.

Importantly, our study does not exclude the notion that lowering $\alpha$ syn may impact other mitochondrial functions, such as mitochondrial $\mathrm{Ca}^{2+}$ import and buffering (Cali et al. 2012; Guardia-Laguarta et al. 2014), reactive oxygen species production, and lipid metabolism (Ellis et al. 2005; Cole et al. 2008; Nakamura et al. 2008; Nunnari and Suomalainen, 2012). Nonetheless, significant changes in any of these parameters would likely affect bioenergetic function and mitochondrial morphology, suggesting that any such changes would likely be subtle.

Our findings show that $\alpha$ syn can be safely lowered in mice without affecting mitochondrial bioenergetics. We believe that these studies suggest that therapeutically lowering $\alpha$ syn is unlikely to further disrupt mitochondrial bioenergetic function in PD. These results will need to be established in humans, especially if intended for therapies for PD patients, which will require many years. Moreover, lowering $\alpha$ syn could also produce toxicity through nonmitochondrial functions, such as disrupting synaptic vesicle release. Considering the rapid development of $\alpha$ synlowering therapies, we can expect to gain new insights into the safety and biological impact of $\alpha$ syn-lowering therapies over the coming decade.

\section{References}

Attwell D, Laughlin SB (2001) An energy budget for signaling in the grey matter of the brain. J Cereb Blood Flow Metab 21:1133-1145. CrossRef Medline

Backman CM, Malik N, Zhang Y, Shan L, Grinberg A, Hoffer BJ, Westphal H, Tomac AC (2006) Characterization of a mouse strain expressing Cre recombinase from the 3' untranslated region of the dopamine transporter locus. Genesis 44:383-390. CrossRef Medline 
Baptista MA, Dave KD, Sheth NP, De Silva SN, Carlson KM, Aziz YN, Fiske BK, Sherer TB, Frasier MA (2013) A strategy for the generation, characterization and distribution of animal models by The Michael J. Fox Foundation for Parkinson's Research. Dis Model Mech 6:1316-1324. CrossRef

Beach TG, Adler CH, Sue LI, Vedders L, Lue L, White lii CL, Akiyama H, Caviness JN, Shill HA, Sabbagh MN, Walker DG, Arizona Parkinson's Disease C (2010) Multi-organ distribution of phosphorylated alpha-synuclein histopathology in subjects with Lewy body disorders. Acta Neuropathol 119:689-702. CrossRef

Beaudoin GM, 3rd, Lee SH, Singh D, Yuan Y, Ng YG, Reichardt LF, Arikkath $\mathrm{J}$ (2012) Culturing pyramidal neurons from the early postnatal mouse hippocampus and cortex. Nat Protoc 7:1741-1754. CrossRef

Bender A, Krishnan KJ, Morris CM, Taylor GA, Reeve AK, Perry RH, Jaros E, Hersheson JS, Betts J, Klopstock T, Taylor RW, Turnbull DM (2006) High levels of mitochondrial DNA deletions in substantia nigra neurons in aging and Parkinson disease. Nat Genet 38:515517. CrossRef Medline

Bendor JT, Logan TP, Edwards RH (2013) The function of alphasynuclein. Neuron 79:1044-1066. CrossRef Medline

Benskey MJ, Sandoval IM, Manfredsson FP (2016a) Continuous Collection of Adeno-Associated Virus from Producer Cell Medium Significantly Increases Total Viral Yield. Hum Gene Ther Methods 27:32-45.

Benskey MJ, Perez RG, Manfredsson FP (2016b) The contribution of alpha synuclein to neuronal survival and function - Implications for Parkinson's disease. J Neurochem 137:331-359.

Berthet A, Margolis EB, Zhang J, Hsieh I, Zhang J, Hnasko TS, Ahmad J, Edwards RH, Sesaki H, Huang EJ, Nakamura K (2014) Loss of mitochondrial fission depletes axonal mitochondria in midbrain dopamine neurons. J Neurosci 34:14304-14317. CrossRef Medline

Butler EK, Voigt A, Lutz AK, Toegel JP, Gerhardt E, Karsten P, Falkenburger B, Reinartz A, Winklhofer KF, Schulz JB (2012) The mitochondrial chaperone protein TRAP1 mitigates alpha-Synuclein toxicity. PLoS Genet 8:e1002488. CrossRef Medline

Cali T, Ottolini D, Negro A, Brini M (2012) alpha-Synuclein controls mitochondrial calcium homeostasis by enhancing endoplasmic reticulum-mitochondria interactions. J Biol Chem 287:1791417929. CrossRef Medline

Chandra S, Fornai F, Kwon HB, Yazdani U, Atasoy D, Liu X, Hammer RE, Battaglia G, German DC, Castillo PE, Sudhof TC (2004) Double-knockout mice for alpha- and beta-synucleins: effect on synaptic functions. Proc Natl Acad Sci U S A 101:14966-14971. CrossRef Medline

Chinta SJ, Mallajosyula JK, Rane A, Andersen JK (2010) Mitochondrial alpha-synuclein accumulation impairs complex I function in dopaminergic neurons and results in increased mitophagy in vivo. Neurosci Lett 486:235-239. CrossRef Medline

Choi SW, Gerencser AA, Lee DW, Rajagopalan S, Nicholls DG, Andersen JK, Brand MD (2011) Intrinsic bioenergetic properties and stress sensitivity of dopaminergic synaptosomes. J Neurosci 31:4524-4534. CrossRef Medline

Choubey V, Safiulina D, Vaarmann A, Cagalinec M, Wareski P, Kuum M, Zharkovsky A, Kaasik A (2011) Mutant A53T alpha-synuclein induces neuronal death by increasing mitochondrial autophagy. $J$ Biol Chem 286:10814-10824. CrossRef Medline

Clark IE, Dodson MW, Jiang C, Cao JH, Huh JR, Seol JH, Yoo SJ, Hay BA, Guo M (2006) Drosophila pink1 is required for mitochondrial function and interacts genetically with parkin. Nature 441: 1162-1166. CrossRef Medline

Cole NB, Dieuliis D, Leo P, Mitchell DC, Nussbaum RL (2008) Mitochondrial translocation of alpha-synuclein is promoted by intracellular acidification. Exp Cell Res 314:2076-2089. CrossRef Medline

Collier TJ, Redmond DE, Jr., Steece-Collier K, Lipton JW, Manfredsson FP (2016) Is Alpha-Synuclein Loss-of-Function a Contributor to Parkinsonian Pathology? Evidence from Non-human Primates. Front Neurosci 10:12 CrossRef
Dauer W, Kholodilov N, Vila M, Trillat AC, Goodchild R, Larsen KE, Staal R, Tieu K, Schmitz Y, Yuan CA, Rocha M, Jackson-Lewis V, Hersch S, Sulzer D, Przedborski S, Burke R, Hen R (2002) Resistance of alpha -synuclein null mice to the parkinsonian neurotoxin MPTP. Proc Natl Acad Sci U S A 99:14524-14529. CrossRef Medline

Dehay B, Bourdenx M, Gorry P, Przedborski S, Vila M, Hunot S, Singleton A, Olanow CW, Merchant KM, Bezard E, Petsko GA, Meissner WG (2015) Targeting alpha-synuclein for treatment of Parkinson's disease: mechanistic and therapeutic considerations. Lancet Neurol 14:855-866. CrossRef Medline

Devi L, Raghavendran V, Prabhu BM, Avadhani NG, Anandatheerthavarada HK (2008) Mitochondrial import and accumulation of alpha-synuclein impair complex I in human dopaminergic neuronal cultures and Parkinson disease brain. J Biol Chem 283:90899100. CrossRef

Di Maio R, Barrett PJ, Hoffman EK, Barrett CW, Zharikov A, Borah A, Hu X, McCoy J, Chu CT, Burton EA, Hastings TG, Greenamyre JT (2016) alpha-Synuclein binds to TOM20 and inhibits mitochondrial protein import in Parkinson's disease. Sci Transl Med 8:342ra378. CrossRef

Ellis CE, Murphy EJ, Mitchell DC, Golovko MY, Scaglia F, BarceloCoblijn GC, Nussbaum RL (2005) Mitochondrial lipid abnormality and electron transport chain impairment in mice lacking alphasynuclein. Mol Cell Biol 25:10190-10201. CrossRef Medline

Funayama M, et al. (2015) CHCHD2 mutations in autosomal dominant late-onset Parkinson's disease: a genome-wide linkage and sequencing study. Lancet Neurol 14:274-282. CrossRef Medline

Gerencser AA, Neilson A, Choi SW, Edman U, Yadava N, Oh RJ, Ferrick DA, Nicholls DG, Brand MD (2009) Quantitative microplatebased respirometry with correction for oxygen diffusion. Anal Chem 81:6868-6878. CrossRef Medline

Gorbatyuk OS, Li S, Nash K, Gorbatyuk M, Lewin AS, Sullivan LF, Mandel RJ, Chen W, Meyers C, Manfredsson FP, Muzyczka N (2010) In vivo RNAi-mediated alpha-synuclein silencing induces nigrostriatal degeneration. Mol Ther 18:1450-1457. CrossRef

Greten-Harrison B, Polydoro M, Morimoto-Tomita M, Diao L, Williams AM, Nie EH, Makani S, Tian N, Castillo PE, Buchman VL, Chandra SS (2010) alphabetagamma-Synuclein triple knockout mice reveal age-dependent neuronal dysfunction. Proc Natl Acad Sci U S A 107:19573-19578. CrossRef Medline

Guardia-Laguarta C, Area-Gomez E, Rub C, Liu Y, Magrane J, Becker D, Voos W, Schon EA, Przedborski S (2014) alphaSynuclein is localized to mitochondria-associated ER membranes. J Neurosci 34:249-259. CrossRef Medline

Gundersen HJ, Jensen EB (1987) The efficiency of systematic sampling in stereology and its prediction. J Microsc 147:229-263. Medline

Hall H, Reyes S, Landeck N, Bye C, Leanza G, Double K, Thompson L, Halliday G, Kirik D (2014) Hippocampal Lewy pathology and cholinergic dysfunction are associated with dementia in Parkinson's disease. Brain 137:2493-2508. CrossRef Medline

Hua Z, Leal-Ortiz S, Foss SM, Waites CL, Garner CC, Voglmaier SM, Edwards RH (2011) v-SNARE composition distinguishes synaptic vesicle pools. Neuron 71:474-487. CrossRef Medline

Imamura $\mathrm{H}$, Nhat KP, Togawa $\mathrm{H}$, Saito $\mathrm{K}$, lino $\mathrm{R}$, Kato-Yamada $\mathrm{Y}$, Nagai T, Noji H (2009a) Visualization of ATP levels inside single living cells with fluorescence resonance energy transfer-based genetically encoded indicators. Proc Natl Acad Sci U S A 106: 15651-15656.

Imamura H, Huynh Nhat KP, Togawa $\mathrm{H}$, Saito K, lino R, KatoYamada Y, Nagai T, Noji H (2009b) Visualization of ATP levels inside single living cells with fluorescence resonance energy transfer-based genetically encoded indicators. Proceedings of the National Academy of Sciences of the United States of America 106:15651-15656.

Iwai A, Masliah E, Yoshimoto M, Ge N, Flanagan L, de Silva HA, Kittel A, Saitoh T (1995) The precursor protein of non-A beta component of Alzheimer's disease amyloid is a presynaptic protein of the central nervous system. Neuron 14:467-475. CrossRef 
Jakes R, Spillantini MG, Goedert M (1994) Identification of two distinct synucleins from human brain. FEBS Lett 345:27-32. Medline

Jiang M, Chen G (2006) High Ca2+-phosphate transfection efficiency in low-density neuronal cultures. Nat Protoc 1:695-700. CrossRef Medline

Kamp F, Exner N, Lutz AK, Wender N, Hegermann J, Brunner B, Nuscher B, Bartels T, Giese A, Beyer K, Eimer S, Winklhofer KF, Haass C (2010) Inhibition of mitochondrial fusion by alphasynuclein is rescued by PINK1, Parkin and DJ-1. EMBO J 29: 3571-3589. CrossRef Medline

Kanaan NM, Manfredsson FP (2012) Loss of functional alpha-synuclein: a toxic event in Parkinson's disease?. J Parkinsons Dis 2:249-267. CrossRef Medline

Klivenyi P, Siwek D, Gardian G, Yang L, Starkov A, Cleren C, Ferrante RJ, Kowall NW, Abeliovich A, Beal MF (2006) Mice lacking alphasynuclein are resistant to mitochondrial toxins. Neurobiol Dis 21: 541-548. CrossRef Medline

Kruger R, Kuhn W, Muller T, Woitalla D, Graeber M, Kosel S, Przuntek H, Epplen JT, Schols L, Riess O (1998) Ala30Pro mutation in the gene encoding alpha-synuclein in Parkinson's disease. Nat Genet 18:106-108. CrossRef Medline

Kuhn M, Haebig K, Bonin M, Ninkina N, Buchman VL, Poths S, Riess O (2007) Whole genome expression analyses of single- and double-knock-out mice implicate partially overlapping functions of alpha- and gamma-synuclein. Neurogenetics 8:71-81. CrossRef Medline

Kuo YM, Nussbaum RL (2015) Prolongation of Chemically-Induced Methemoglobinemia in Mice Lacking alpha-synuclein: A Novel Pharmacologic and Toxicologic Phenotype. Toxicol Rep 2:504511. CrossRef Medline

Li L, Nadanaciva S, Berger Z, Shen W, Paumier K, Schwartz J, Mou K, Loos P, Milici AJ, Dunlop J, Hirst WD (2013) Human A53T alpha-synuclein causes reversible deficits in mitochondrial function and dynamics in primary mouse cortical neurons. PLoS One 8:e85815. CrossRef Medline

Li WW, Yang R, Guo JC, Ren HM, Zha XL, Cheng JS, Cai DF (2007) Localization of alpha-synuclein to mitochondria within midbrain of mice. Neuroreport 18:1543-1546. CrossRef Medline

Liu G, Zhang C, Yin J, Li X, Cheng F, Li Y, Yang H, Ueda K, Chan P, Yu $S$ (2009) alpha-Synuclein is differentially expressed in mitochondria from different rat brain regions and dose-dependently down-regulates complex I activity. Neurosci Lett 454:187-192. CrossRef Medline

Loeb V, Yakunin E, Saada A, Sharon R (2010) The transgenic over expression of alpha-synuclein and not its related pathology, associates with complex I inhibition. J Biol Chem 285:7334-7343. CrossRef Medline

Ludtmann MH, Angelova PR, Ninkina NN, Gandhi S, Buchman VL, Abramov AY (2016) Monomeric Alpha-Synuclein Exerts a Physiological Role on Brain ATP Synthase. J Neurosci 36:10510-10521. CrossRef Medline

Luth ES, Stavrovskaya IG, Bartels T, Kristal BS, Selkoe DJ (2014) Soluble, prefibrillar alpha-synuclein oligomers promote complex I-dependent, $\mathrm{Ca} 2+$-induced mitochondrial dysfunction. J Biol Chem 289:21490-21507. CrossRef Medline

Lysko PG, Webb CL, Yue TL, Gu JL, Feuerstein G (1994) Neuroprotective effects of tetrodotoxin as a $\mathrm{Na}+$ channel modulator and glutamate release inhibitor in cultured rat cerebellar neurons and in gerbil global brain ischemia. Stroke 25:2476-2482. Medline

Martin LJ, Pan Y, Price AC, Sterling W, Copeland NG, Jenkins NA, Price DL, Lee MK (2006) Parkinson's disease alpha-synuclein transgenic mice develop neuronal mitochondrial degeneration and cell death. J Neurosci 26:41-50. CrossRef Medline

McCormack AL, Mak SK, Henderson JM, Bumcrot D, Farrer MJ, Di Monte DA (2010) Alpha-synuclein suppression by targeted small interfering RNA in the primate substantia nigra. PLoS One 5:e12122. CrossRef Medline

Millership S, Ninkina N, Guschina IA, Norton J, Brambilla R, Oort PJ, Adams SH, Dennis RJ, Voshol PJ, Rochford JJ, Buchman VL
(2012) Increased lipolysis and altered lipid homeostasis protect gamma-synuclein-null mutant mice from diet-induced obesity. Proc Natl Acad Sci U S A 109:20943-20948. CrossRef Medline

Nakamura K (2013) alpha-Synuclein and mitochondria: partners in crime?. Neurotherapeutics 10:391-399. CrossRef Medline

Nakamura K, Nemani VM, Wallender EK, Kaehlcke K, Ott M, Edwards RH (2008) Optical reporters for the conformation of alphasynuclein reveal a specific interaction with mitochondria. J Neurosci 28:12305-12317. CrossRef Medline

Nakamura K, Nemani VM, Azarbal F, Skibinski G, Levy JM, Egami K, Munishkina L, Zhang J, Gardner B, Wakabayashi J, Sesaki H, Cheng Y, Finkbeiner S, Nussbaum RL, Masliah E, Edwards RH (2011) Direct membrane association drives mitochondrial fission by the Parkinson disease-associated protein alpha-synuclein. J Biol Chem 286:20710-20726. CrossRef Medline

Nemani VM, Lu W, Berge V, Nakamura K, Onoa B, Lee MK, Chaudhry FA, Nicoll RA, Edwards RH (2010) Increased expression of alpha-synuclein reduces neurotransmitter release by inhibiting synaptic vesicle reclustering after endocytosis. Neuron 65:66-79. CrossRef Medline

Norris KL, Hao R, Chen LF, Lai CH, Kapur M, Shaughnessy PJ, Chou D, Yan J, Taylor JP, Engelender S, West AE, Lim KL, Yao TP (2015) Convergence of Parkin, PINK1, and alpha-Synuclein on Stressinduced Mitochondrial Morphological Remodeling. J Biol Chem 290:13862-13874. CrossRef Medline

Nunnari J, Suomalainen A (2012) Mitochondria: in sickness and in health. Cell 148:1145-1159. CrossRef Medline

Park J, Lee SB, Lee S, Kim Y, Song S, Kim S, Bae E, Kim J, Shong M, Kim JM, Chung J (2006) Mitochondrial dysfunction in Drosophila PINK1 mutants is complemented by parkin. Nature 441:11571161. CrossRef Medline

Pathak D, Shields LY, Mendelsohn BA, Haddad D, Lin W, Gerencser AA, Kim H, Brand MD, Edwards RH, Nakamura K (2015) The role of mitochondrially derived ATP in synaptic vesicle recycling. J Biol Chem 290:22325-22336. CrossRef Medline

Polymeropoulos MH, Lavedan C, Leroy E, Ide SE, Dehejia A, Dutra A, Pike B, Root H, Rubenstein J, Boyer R, Stenroos ES, Chandrasekharappa S, Athanassiadou A, Papapetropoulos T, Johnson WG, Lazzarini AM, Duvoisin RC, Di lorio G, Golbe LI, Nussbaum RL (1997) Mutation in the alpha-synuclein gene identified in families with Parkinson's disease. Science 276:2045-2047. Medline

Rangaraju V, Calloway N, Ryan TA (2014) Activity-driven local ATP synthesis is required for synaptic function. Cell 156:825-835. CrossRef Medline

Robertson DC, Schmidt O, Ninkina N, Jones PA, Sharkey J, Buchman VL (2004) Developmental loss and resistance to MPTP toxicity of dopaminergic neurones in substantia nigra pars compacta of gamma-synuclein, alpha-synuclein and double alpha/gammasynuclein null mutant mice. J Neurochem 89:1126-1136. CrossRef Medline

Sampaio-Marques B, Felgueiras C, Silva A, Rodrigues M, Tenreiro S, Franssens V, Reichert AS, Outeiro TF, Winderickx J, Ludovico P (2012) SNCA (alpha-synuclein)-induced toxicity in yeast cells is dependent on sirtuin 2 (Sir2)-mediated mitophagy. Autophagy 8:1494-1509.

Schapira AH, Cooper JM, Dexter D, Clark JB, Jenner P, Marsden CD (1990) Mitochondrial complex I deficiency in Parkinson's disease. J Neurochem 54:823-827. Medline

Scott DA, Tabarean I, Tang Y, Cartier A, Masliah E, Roy S (2010) A pathologic cascade leading to synaptic dysfunction in alphasynuclein-induced neurodegeneration. J Neurosci 30:8083-8095. CrossRef Medline

Shields LY, Kim H, Zhu L, Haddad D, Berthet A, Pathak D, Lam M, Ponnusamy R, Diaz-Ramirez LG, Gill TM, Sesaki H, Mucke L, Nakamura K (2015) Dynamin-related protein 1 is required for normal mitochondrial bioenergetic and synaptic function in CA1 hippocampal neurons. Cell Death Dis 6:e1725. CrossRef Medline

Singleton AB, et al. (2003) alpha-Synuclein locus triplication causes Parkinson's disease. Science 302:841. CrossRef Medline 
Sohal VS, Zhang F, Yizhar O, Deisseroth K (2009) Parvalbumin neurons and gamma rhythms enhance cortical circuit performance. Nature 459:698-702. CrossRef Medline

Spillantini MG, Crowther RA, Jakes R, Hasegawa M, Goedert M (1998) alpha-Synuclein in filamentous inclusions of Lewy bodies from Parkinson's disease and dementia with lewy bodies. Proc Natl Acad Sci U S A 95:6469-6473. Medline

Subach OM, Gundorov IS, Yoshimura M, Subach FV, Zhang J, Gruenwald D, Souslova EA, Chudakov DM, Verkhusha VV (2008) Conversion of red fluorescent protein into a bright blue probe. Chem Biol 15:1116-1124. CrossRef Medline

Taschenberger G, Toloe J, Tereshchenko J, Akerboom J, Wales P, Benz R, Becker S, Outeiro TF, Looger LL, Bahr M, Zweckstetter M, Kugler S (2013) beta-synuclein aggregates and induces neurodegeneration in dopaminergic neurons. Ann Neurol 74:109-118. CrossRef Medline

Thomas B, Mandir AS, West N, Liu Y, Andrabi SA, Stirling W, Dawson VL, Dawson TM, Lee MK (2011) Resistance to MPTPneurotoxicity in alpha-synuclein knockout mice is complemented by human alpha-synuclein and associated with increased betasynuclein and Akt activation. PLoS One 6:e16706. CrossRef Medline

Valente EM, et al. (2004) Hereditary early-onset Parkinson's disease caused by mutations in PINK1. Science 304:1158-1160. CrossRef Medline

van Rooijen BD, Claessens MM, Subramaniam V (2009) Lipid bilayer disruption by oligomeric alpha-synuclein depends on bilayer charge and accessibility of the hydrophobic core. Biochim Biophys Acta 1788:1271-1278. CrossRef Medline
Voglmaier SM, Kam K, Yang H, Fortin DL, Hua Z, Nicoll RA, Edwards $\mathrm{RH}$ (2006) Distinct endocytic pathways control the rate and extent of synaptic vesicle protein recycling. Neuron 51:71-84. CrossRef Medline

Volpicelli-Daley LA, Luk KC, Patel TP, Tanik SA, Riddle DM, Stieber A, Meaney DF, Trojanowski JQ, Lee VM (2011) Exogenous alphasynuclein fibrils induce Lewy body pathology leading to synaptic dysfunction and neuron death. Neuron 72:57-71. CrossRef Medline

Xia Z, Liu Y (2001) Reliable and global measurement of fluorescence resonance energy transfer using fluorescence microscopes. Biophys J 81:2395-2402. CrossRef Medline

Yao J, Chen S, Mao Z, Cadenas E, Brinton RD (2011) 2-Deoxy-Dglucose treatment induces ketogenesis, sustains mitochondrial function, and reduces pathology in female mouse model of Alzheimer's disease. PLoS One 6:e21788. CrossRef Medline

Yu J, Sadhukhan S, Noriega LG, Moullan N, He B, Weiss RS, Lin H, Schoonjans K, Auwerx J (2013) Metabolic characterization of a Sirt5 deficient mouse model. Sci Rep 3:2806. CrossRef Medline

Zarranz JJ, Alegre J, Gomez-Esteban JC, Lezcano E, Ros R, Ampuero I, Vidal L, Hoenicka J, Rodriguez O, Atares B, Llorens V, Gomez Tortosa E, del Ser T, Munoz DG, de Yebenes JG (2004) The new mutation, E46K, of alpha-synuclein causes Parkinson and Lewy body dementia. Ann Neurol 55:164-173. CrossRef Medline Zharikov AD, Cannon JR, Tapias V, Bai Q, Horowitz MP, Shah V, El Ayadi A, Hastings TG, Greenamyre JT, Burton EA (2015) shRNA targeting alpha-synuclein prevents neurodegeneration in a Parkinson's disease model. J Clin Invest 125:2721-2735. CrossRef

Zheng B, et al. (2010) PGC-1alpha, a potential therapeutic target for early intervention in Parkinson's disease. Sci Transl Med 2:52ra73 